\title{
Long-Term Metal-Content Changes in Soils on the Olkusz Zn-Pb Ore-Bearing Area, Poland
}

\author{
Agnieszka Gruszecka-Kosowska $^{1}$ Alicja Kicińska1
}

Received: 1 January 2017/Revised: 8 June 2017/ Accepted: 16 June 2017/Published online: 1 July 2017

(C) The Author(s) 2017. This article is an open access publication

\begin{abstract}
Long-term changes of As, $\mathrm{Cd}, \mathrm{Fe}, \mathrm{Pb}, \mathrm{Tl}, \mathrm{Zn}, \mathrm{Cl}^{-}$, $\mathrm{SO}_{4}{ }^{2-}$, and $\mathrm{PO}_{4}{ }^{2-}$ contents were calculated in topsoil samples and soil profiles in the vicinity of the $\mathrm{Zn}-\mathrm{Pb}$ mine and processing plant at Bukowno, Poland. Evaluations were based on research results obtained in 1994-2014. Soil was described on the basis of hand specimens for which the following were determined: active and potential $\mathrm{pH}$, organic matter content, moisture content, buffer properties, total metal content $\left(\mathrm{HCl}+\mathrm{HNO}_{3} 3: 1\right)$, forms of binding metals (using the BCR sequential extraction procedure), metal bioavailability (extraction by the 0.05 M EDTA solution), and water leaching of metals. Soil contamination was determined by the contamination factor and the pollution load index. The potential environmental risk was determined by the risk assessment code (RAC). Twenty-year-long research demonstrated the trend of decreasing metal content in topsoil. The sampling sites, selected in close vicinity of the flotation tailings dump, showed increasing contents of As, $\mathrm{Pb}$, and $\mathrm{Cd}$. The metal content in soil profiles revealed a significant decrease with time. Metal bioavailability, tested in all soil samples, indicated that the exchangeable forms were carriers of mainly Cd (up to $83 \%$ ), $\mathrm{Zn}$ (up to $72 \%$ ), and $\mathrm{Pb}$ (up to 60\%) (the proportions refer to total metal contents), whereas $\mathrm{As}, \mathrm{Fe}$, and $\mathrm{Tl}$ were bound either with hardly movable forms or remained in the extraction residuum. The RAC showed medium to high environmental risks in soils, caused by the presence of $\mathrm{Cd}, \mathrm{Zn}, \mathrm{Pb}$, and $\mathrm{Tl}$.
\end{abstract}

Agnieszka Gruszecka-Kosowska

agnieszka.gruszecka@agh.edu.pl

1 Department of Environmental Protection, Faculty of Geology, Geophysics, and Environmental Protection, AGH University of Science and Technology, Al. A. Mickiewicza 30, 30-059 Kraków, Poland
Keywords Soil pollution $\cdot \mathrm{Zn}-\mathrm{Pb}$ ores $\cdot$ Historical mining · Contamination factor $\cdot$ Risk assessment code . Pollution load index

$\begin{array}{ll}\text { Abbreviations } \\ \text { BCR } & \begin{array}{l}\text { Community Bureau of Reference BCR sequential } \\ \text { extraction procedure }\end{array} \\ \text { bgl } & \begin{array}{l}\text { Belowground level } \\ \text { CF }\end{array} \\ \text { Contamination Factor } \\ \text { EDTA } & \text { Ethylenediaminetetraacetic acid } \\ \text { L/S } & \text { Liquid to solid ratio } \\ \text { OM } & \text { Organic matter } \\ \text { PHE } & \text { Potential harmful elements } \\ \text { PLI } & \text { Pollution load index } \\ \text { RAC } & \text { Risk assessment code } \\ \text { S } & \text { Contamination index } \\ \text { SD } & \text { Standard deviation } \\ \text { WHO } & \text { World Health Organization }\end{array}$

\section{Introduction}

The Silesia-Małopolska $\mathrm{Zn}-\mathrm{Pb}$ ore-bearing region, occupying ca. $1200 \mathrm{~km}^{2}$, is one of the largest in the world (Bilans 2013). It is divided into two sections: the Upper Silesian Coal Basin and the northwestern margin encompassing the Olkusz ore-bearing area (Małopolska Region). The Olkusz deposits are rich in epigenetic ore-bearing dolomites, within the paleosome of the Triassic and Devonian carbonate rocks (Sass-Gustkiewicz 1995, 1996), and they belong to the Mississippi Valley type (MVT) of deposits. As such, they have a relatively simple mineral composition, represented by the galena and polymorphic varieties of $\mathrm{Zn}$ and $\mathrm{Fe}$ sulphides. The Triassic is overlain by limestone and clay strata of the Jurassic, whereas 
morphological depressions are filled with the Pleistocene and Holocene sediments, mainly clay-sandy ones.

Complex geological structures, resulting mainly from tectonic events, caused that subsurface deposits became exposed to hypergenic factors. In consequence, the nearsurface ore outcrops were oxidized (Cabała 2001) and some soils obtained natural geochemical-dispersion aureoles, including those with $\mathrm{Zn}, \mathrm{Pb}$, and $\mathrm{Cd}$ (Sass-Gustkiewicz 1997; Sass-Gustkiewicz et al. 2001; Trafas et al. 2006). The products of mining and ore processing were easily leachable and that is why the component metals often penetrated soil solutions, which generally occurred in the historical ore mining and metallurgical regions. $\mathrm{Li}$ and Thornton (2001) stressed that issue since significant amounts of the potential harmful elements (PHE) may enter a trophic chain and affect living organisms (WHO 1988).

\section{Emission Sources and Volumes}

Pollution of the Olkusz ore-bearing area was caused by ore-bearing dolomite mining followed by metal extraction (initially $\mathrm{Ag}$, later $\mathrm{Pb}$, and $\mathrm{Zn}-\mathrm{Pb}$ currently). The ore exploitation began in the eleventh century there (Majcherek 1991; Janusz and Popiołek 1993; Sass-Gustkiewicz et al. 2001), but the most serious pollution rates resulted from mining and other industrial activities in the last 50 years (Nowicki 1993; Girczys and Sobik-Szołtysek 2002; Cabała 2010; Paulo and Wnuk 2012).

Major pollutants originated from two sources: the ZGH "Bolesław" Mining and Metallurgical Plants in Bukowno and the whole Upper Silesian region, owing to long-distance atmospheric transport and deposition of dusts containing heavy metals such as $\mathrm{Pb}, \mathrm{Zn}, \mathrm{Cd}, \mathrm{Tl}$, and $\mathrm{As}$ (Dworak and Czubak 1990; Kapeja et al. 1990; Chodak et al. 2013; Miśkowiec et al. 2015). The ZGH "Bolesław" activities entailed underground ore mining in the "Bolesław" (closed in 1998), "Olkusz" (closed in 2003), and "Pomorzany" (still active) mines. Environmental problems became aggravated in the area due to secondary dusting from unprotected disposal sites, dumps, and settlements, contaminating the atmosphere with particulates carrying significant amounts of heavy metals (Kicki 1997; Sroczyński 1997; Danek 2007; SzarekŁukaszewska and Grodzińska 2011; Kapusta and Sobczyk 2015). Additional problems were generated by pollutant re-emission from uncovered bedrock (Dmuchowski et al. 2011).

Ore processing generates the highest volume of waste materials. It starts with the gravitational treatment. Tailings are later utilized as rock aggregate and the material is treated in the flotation plant. Primary flotation tailings are re-processed as the so-called poor ores. Their volume is decreasing, while the volume of the final flotation tailings is increasing. The latter are troublesome not only in terms of amounts, but because of limited possibilities of further use. For that reason, tailings must be disposed of on surface dumps. Tailing heaps are a real landscape nuisance and they constitute a source of secondary dusting and migration of metals (Girczys and Sobik-Szołtysek 2002; Cabała 2009).

\section{Heavy Metals in Soil}

The analysis of the area's soil composition has been carried out since the 1960s and those indicated contamination with heavy metals (Gruszczyński et al. 1990; Gorlach and Gambuś 1995; Trafas et al. 2006; Kicińska-Świderska 2004; Krzaklewski et al. 2004; Gruszecka 2011; Kicińska and Wójcik 2011; Pająk et al. 2012; Stefanowicz et al. 2014; Pajak et al. 2016). The highest amounts of $\mathrm{Zn}, \mathrm{Pb}$, and $\mathrm{Cd}$ in soils were found in the places of historical ore exploitation and processing (Chrastný et al. 2012; Pająk et al. 2015). In Bukowno, Sławków and Strzemieszyce, the soils contained up to $25,000 \mathrm{mg} / \mathrm{kg}$ of $\mathrm{Zn}, 5,000 \mathrm{mg} / \mathrm{kg}$ of $\mathrm{Pb}, 129 \mathrm{mg} / \mathrm{kg}$ of $\mathrm{Cd}$, and $39 \mathrm{mg} / \mathrm{kg}$ of $\mathrm{Tl}$, as well as elevated amounts of $\mathrm{Fe}$ and $\mathrm{Mn}$ (Cabała 2009). The highest metal contents were found in topsoil down to $25 \mathrm{~cm}$ below the ground level (bgl), but they significantly decreased when going deeper into the profile (Kicińska-Świderska 1999; Kicińska 2009; Gruszecka and Wdowin 2013; Baran et al. 2014). Lead was the metal showing the strongest accumulation in topsoil (Verner et al. 1996; Cabała 2009), with $\mathrm{Cd}$ and $\mathrm{Zn}$, being more mobile, distributed more uniformly within soil profiles (Kabata-Pendias 1989; Trafas et al. 1990; Kicińska 2011).

\section{Chemical Monitoring of Soil by the Polish Environment Monitoring System in 1994-2014}

Soil quality and ground monitoring has been carried out in Poland by the Institute of Soil Science and Plant Cultivation in Puławy. Based on that domestic monitoring network, distributed on arable lands, evaluations of soil quality have been conducted at 216 grid points every 5 years since 1995 . The following grid points are located close to the Olkusz ore-bearing area: No. 347 Oświęcim (Małopolska Region), No. 345 Komołów, No. 343 Sulików, and No. 409 Goczałkowice (former Ćwiklice, all three in Silesia). The $\mathrm{Cd}, \mathrm{Pb}$, and $\mathrm{Zn}$ contents in soil indicated that the permissible limits established by the Puławy Institute (Kabata-Pendias et al. 1993, 1995) were not exceeded at three out of the four grid points. However, grid point No. 343 Sulików was the exception: the $\mathrm{Cd}$ content exceeded the limits twice, $\mathrm{Pb}$ content ten times, and that of $\mathrm{Zn}$ more than five times (Table 1). 
Table 1 Selected physico-chemical parameters for arable soils in the vicinity of the Olkusz ore-bearing area (after Monitoring gleb ornych., 1995-2010)

\begin{tabular}{|c|c|c|c|c|c|c|c|}
\hline \multirow[t]{2}{*}{ Grid point } & \multirow[t]{2}{*}{ Characteristics } & \multirow[t]{2}{*}{ Unit } & \multicolumn{4}{|l|}{ Year } & \multirow{2}{*}{$\begin{array}{l}\text { Threshold value } \\
\text { for arable soils } \\
\text { (RMŚ 2002) }\end{array}$} \\
\hline & & & 1995 & 2000 & 2005 & 2010 & \\
\hline \multirow[t]{8}{*}{$\begin{array}{l}347 \text { Oświęcim, Małopolska, } 40 \mathrm{~km} \\
\text { SW from the ZGH "Bolesław" }\end{array}$} & $\begin{array}{c}\text { Soil type (Polish Standard } \\
\text { BN-78/9180-11 1978) }\end{array}$ & $\mathrm{n} / \mathrm{a}$ & \multicolumn{4}{|c|}{ Clay dust } & $\mathrm{n} / \mathrm{a}$ \\
\hline & $\mathrm{pH}_{\mathrm{H}_{2} \mathrm{O}}$ & $\mathrm{n} / \mathrm{a}$ & 6.2 & 6.6 & 6.6 & 6.8 & - \\
\hline & $\mathrm{pH}_{\mathrm{KCl}}$ & $\mathrm{n} / \mathrm{a}$ & 5.1 & 5.4 & 5.6 & 5.9 & - \\
\hline & $\mathrm{OM}$ & $\%$ & 2.8 & 2.7 & 2.5 & 2.5 & - \\
\hline & $\mathrm{Cd}$ & $\mathrm{mg} / \mathrm{kg}$ & 1.0 & 0.9 & 0.8 & 0.4 & 4 \\
\hline & $\mathrm{Pb}$ & $\mathrm{mg} / \mathrm{kg}$ & 43.5 & 44.3 & 41.3 & 23.3 & 100 \\
\hline & $\mathrm{Zn}$ & $\mathrm{mg} / \mathrm{kg}$ & 67.3 & 61.7 & 72.0 & 92.0 & 300 \\
\hline & $\mathrm{Fe}$ & $\%$ & 1.0 & 0.9 & 1.0 & 1.5 & - \\
\hline \multirow[t]{8}{*}{$\begin{array}{l}343 \text { Sulików, Silesia, } 40 \mathrm{~km} \text { NW from } \\
\text { the ZGH "Bolesław" }\end{array}$} & $\begin{array}{l}\text { Soil type (Polish Standard } \\
\text { BN-78/9180-11) }\end{array}$ & $\mathrm{n} / \mathrm{a}$ & \multicolumn{4}{|c|}{ Strong clay sand } & $\mathrm{n} / \mathrm{a}$ \\
\hline & $\mathrm{pH}_{\mathrm{H}_{2} \mathrm{O}}$ & $\mathrm{n} / \mathrm{a}$ & 7.4 & 7.8 & 7.4 & 8.0 & - \\
\hline & $\mathrm{pH}_{\mathrm{KCl}}$ & $\mathrm{n} / \mathrm{a}$ & 6.7 & 7.0 & 6.6 & 7.3 & - \\
\hline & $\mathrm{OM}$ & $\%$ & 1.7 & 1.6 & 1.6 & 2.5 & - \\
\hline & $\mathrm{Cd}$ & $\mathrm{mg} / \mathrm{kg}$ & 5.2 & 5.2 & 5.0 & 10.4 & 4 \\
\hline & $\mathrm{Pb}$ & $\mathrm{mg} / \mathrm{kg}$ & 1050 & 1073 & 1033 & 965 & 100 \\
\hline & $\mathrm{Zn}$ & $\mathrm{mg} / \mathrm{kg}$ & 253 & 318 & 285 & 1627 & 300 \\
\hline & $\mathrm{Fe}$ & $\%$ & 0.8 & 0.7 & 0.7 & 1.3 & - \\
\hline \multirow[t]{8}{*}{$\begin{array}{l}345 \text { Komołów, Silesia, } 30 \mathrm{~km} \mathrm{~N} \text { from } \\
\text { the ZGH "Bolesław" }\end{array}$} & $\begin{array}{l}\text { Soil type (Polish Standard } \\
\text { BN-78/9180-11) }\end{array}$ & $\mathrm{n} / \mathrm{a}$ & \multicolumn{4}{|c|}{ Sandy clay } & $\mathrm{n} / \mathrm{a}$ \\
\hline & $\mathrm{pH}_{\mathrm{H}_{2} \mathrm{O}}$ & $\mathrm{n} / \mathrm{a}$ & 7.1 & 7.3 & 7.2 & 7.7 & - \\
\hline & $\mathrm{pH}_{\mathrm{KCl}}$ & $\mathrm{n} / \mathrm{a}$ & 6.5 & 6.8 & 6.6 & 7.1 & - \\
\hline & $\mathrm{OM}$ & $\%$ & 2.0 & 2.0 & 1.9 & 2.1 & - \\
\hline & $\mathrm{Cd}$ & $\mathrm{mg} / \mathrm{kg}$ & 2.2 & 2.4 & 2.0 & 1.2 & 4 \\
\hline & $\mathrm{Pb}$ & $\mathrm{mg} / \mathrm{kg}$ & 40.4 & 48.5 & 49.2 & 46 & 100 \\
\hline & $\mathrm{Zn}$ & $\mathrm{mg} / \mathrm{kg}$ & 160 & 170 & 168 & 177 & 300 \\
\hline & $\mathrm{Fe}$ & $\%$ & 0.8 & 0.8 & 0.7 & 0.9 & - \\
\hline \multirow[t]{8}{*}{$\begin{array}{l}409 \text { Goczałkowice, Silesia, } 80 \mathrm{~km} \mathrm{SW} \\
\text { from the ZGH "Bolesław" }\end{array}$} & $\begin{array}{l}\text { Soil type (Polish Standard } \\
\text { BN-78/9180-11) }\end{array}$ & $\mathrm{n} / \mathrm{a}$ & \multicolumn{4}{|c|}{ Dusty silt } & $\mathrm{n} / \mathrm{a}$ \\
\hline & $\mathrm{pH}_{\mathrm{H}_{2} \mathrm{O}}$ & $\mathrm{n} / \mathrm{a}$ & 5.3 & 6.2 & 5.9 & 6.6 & - \\
\hline & $\mathrm{pH}_{\mathrm{KCl}}$ & $\mathrm{n} / \mathrm{a}$ & 4.1 & 5.0 & 5.1 & 5.3 & - \\
\hline & $\mathrm{OM}$ & $\%$ & 2.4 & 2.2 & 1.9 & 2.3 & - \\
\hline & $\mathrm{Cd}$ & $\mathrm{mg} / \mathrm{kg}$ & 0.8 & 1.0 & 0.8 & 0.9 & 4 \\
\hline & $\mathrm{Pb}$ & $\mathrm{mg} / \mathrm{kg}$ & 27.2 & 28.3 & 31.2 & 34.7 & 100 \\
\hline & $\mathrm{Zn}$ & $\mathrm{mg} / \mathrm{kg}$ & 73.3 & 71.7 & 76.5 & 119 & 300 \\
\hline & $\mathrm{Fe}$ & $\%$ & 1.2 & 1.2 & 1.1 & 1.2 & - \\
\hline
\end{tabular}

n/a not applicable

- lack of data

The ore-bearing area is mainly covered by industrial facilities which are not subjected to regular soil monitoring under the Polish Environment Monitoring System. Permissible metal contents in soil and surface are thus evaluated on the basis of the Regulation of the Minister of the Environment on soil and ground quality standards (RMŚ 2002), according to which the area under discussion belongs to Group $\mathrm{C}$ of industrial areas. However, local people still use their garden plots around their houses as arable land, disregarding the government rating and the high amounts of heavy metals in topsoil.

The authors intended to evaluate the following: (1) degree of topsoil pollution depending on the distance from major sources of pollution; (2) migration and mobility of elements in soil profiles; (3) impact of the pollutants on plants, based on the determination of bioavailable forms of 


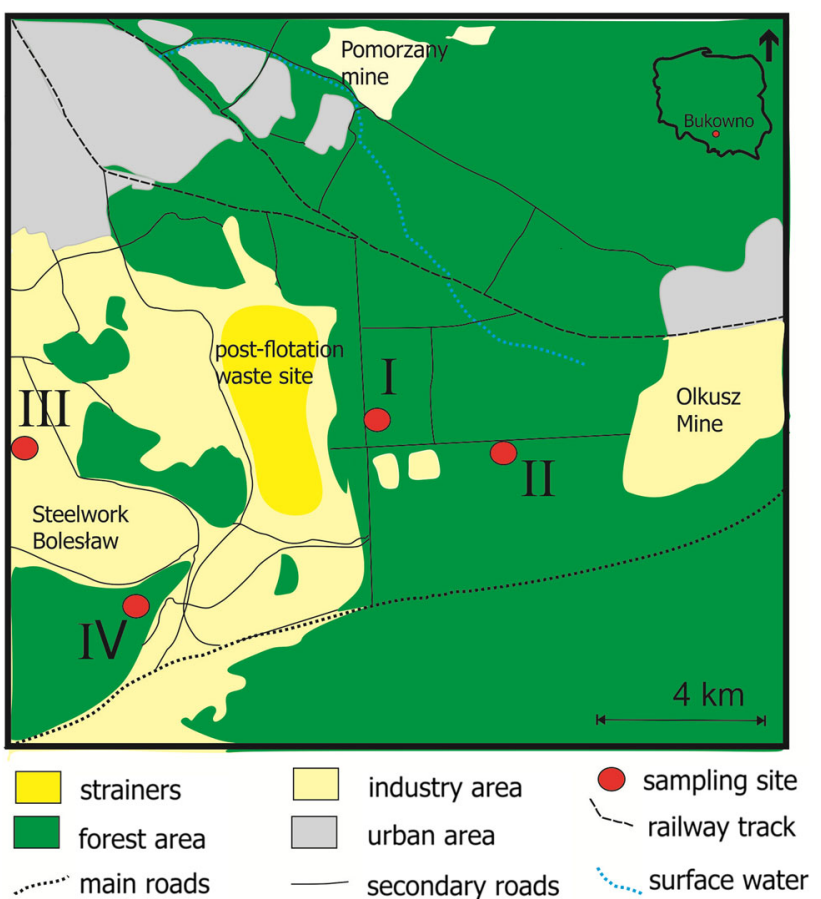

I - N $50^{\circ} 16^{\prime} 53^{\prime \prime} \mathrm{E} 19^{\circ} 30^{\prime} 14^{\prime \prime}$

II - N $50^{\circ} 16^{\prime} 51^{\prime \prime}$ E $19^{\circ} 30^{\prime} 51^{\prime \prime}$

III - N $50^{\circ} 16^{\prime} 38^{\prime \prime} \mathrm{E} 19^{\circ} 28^{\prime} 14^{\prime \prime}$

IV - N $50^{\circ} 16^{\prime} 38^{\prime \prime} \mathrm{E} 19^{\circ} 28^{\prime} 13^{\prime \prime}$

Fig. 1 Locations of sampling Sites (I-IV) in the Olkusz area

metals in soil; (4) changes occurring in the soil environment in the last 20 years, with the identification of reasons; and (5) preliminary environmental risk resulting from soil pollution with heavy metals on the Olkusz ore-bearing area.

\section{Materials and Methods}

Four sites situated at different distances (from 50 to $750 \mathrm{~m}$ ) from the metallurgical plant and the disposal sites of the ZGH "Bolesław" Mine, representing the most dominant wind direction (which in Poland are west wind directions), were sampled in September 2014. 20 topsoil samples were collected from 0 to $20 \mathrm{~cm}$ interval, $1 \mathrm{~kg}$ each. At two sites (sampling Sites I and II), where the concentrations of metals were later found to be the highest, soil profiles were dug down to the depth of $60 \mathrm{~cm}$ and sampled at $10-\mathrm{cm}$ intervals. The sampling sites of 2014 were exactly the same as those of 1994, 2004, and 2009 (Fig. 1). Next, four representative samples of topsoil and 12 samples of two soil profiles were prepared by homogenization and averaging. The samples were dried up to the air-dry state and analysed at the Laboratory of Environmental Analyses of the Faculty of Geology, Geophysics and Environment
Protection of the AGH University of Science and Technology. Soil analyses and determinations concerned the following: hand-specimen observations; physical and mechanical properties, with organic matter content; active $\mathrm{pH}\left(\mathrm{pH}_{\mathrm{H}_{2} \mathrm{O}}\right)$ and potential $\mathrm{pH}\left(\mathrm{pH}_{\mathrm{KCl}}\right)$ (in reference to Polish Standard PN-ISO 10390:1997); buffer properties according to the Arrhenius method (Bednarek et al. 2004); and chemical assays. The latter (see Fig. 2) included the total content of $\mathrm{As}, \mathrm{Cd}, \mathrm{Fe}, \mathrm{Pb}, \mathrm{Tl}$, and $\mathrm{Zn}$ after decomposition in aqua regia (Polish Standard PN-ISO 11466:2002), water leaching of the metals (liquid to solid ratio $L / S=10: 1$ ), the contents of $\mathrm{Cl}^{-}, \mathrm{NO}_{3}{ }^{-}, \mathrm{PO}_{4}{ }^{3-}$ and $\mathrm{SO}_{4}{ }^{2-}$ in soil water solutions $(L / S=10: 1)$; the forms of occurrence of the heavy metals in specified steps of binding, according to the three-step BCR sequential extraction procedure (Quevauviller et al. 1997; Nannoni et al. 2011); and metal bioavailability using the $0.05 \mathrm{M}$ EDTA extraction $(L / S=10: 1)$ procedure. The contents of As, $\mathrm{Cd}, \mathrm{Fe}$, $\mathrm{Pb}, \mathrm{Tl}$, and $\mathrm{Zn}$ were determined with the ICP-MS apparatus (ELAN DRC-e Perkin Elmer) in triplicate and including blank samples, while the concentrations of $\mathrm{Cl}^{-}, \mathrm{NO}_{3}{ }^{-}$, $\mathrm{PO}_{4}{ }^{3-}$ and $\mathrm{SO}_{4}{ }^{2-}$ were established with the IC ion chromatography apparatus (DIONEX DX-100).

\section{Results}

\section{Hand-Specimen Descriptions}

The soils from the Olkusz area were strongly degraded and transformed because of long-term $\mathrm{Zn}-\mathrm{Pb}$ ore mining activities and often covered by thick layers of eolian sands. The soils belonged mainly to the rendzina type, with scarce brown soil occurrence. Initial rendzina soil developed on the historical mining sites (Cabała 2009). However, various types of soil can be found in morphological depressions filled with Pleistocene-Holocene sediments.

Field- and hand-specimen observations determined specific properties of soils. The soil sample of Site I was collected ca. $100 \mathrm{~m} \mathrm{E}$ (east) of the flotation tailings dump of the ZGH "Bolesław" Mine at Bukowno. Its colour was brown to brownish. It was composed mainly of mineral grains representing the aleurite-silt fraction (VF-very fine, grain diameter: $\Phi=3-4$, where $\Phi=\log _{2} d$ in mm) and the silt fraction ( $S$-silt, grain diameter: $\Phi=4-8$ ), the sample contained large fragments of plants. Size terms of mineral fractions used by authors are given in Table 2. A strong reaction with $\mathrm{HCl}$ indicated the presence of at least several percents of carbonates. The following observations were made in respect of the $60-\mathrm{cm}$-long soil profile:

- $0-10 \mathrm{~cm}$ bgl (belowground level); quartz grains dominated, they represented the fractions $\mathrm{F}$ - fine (diameter: 


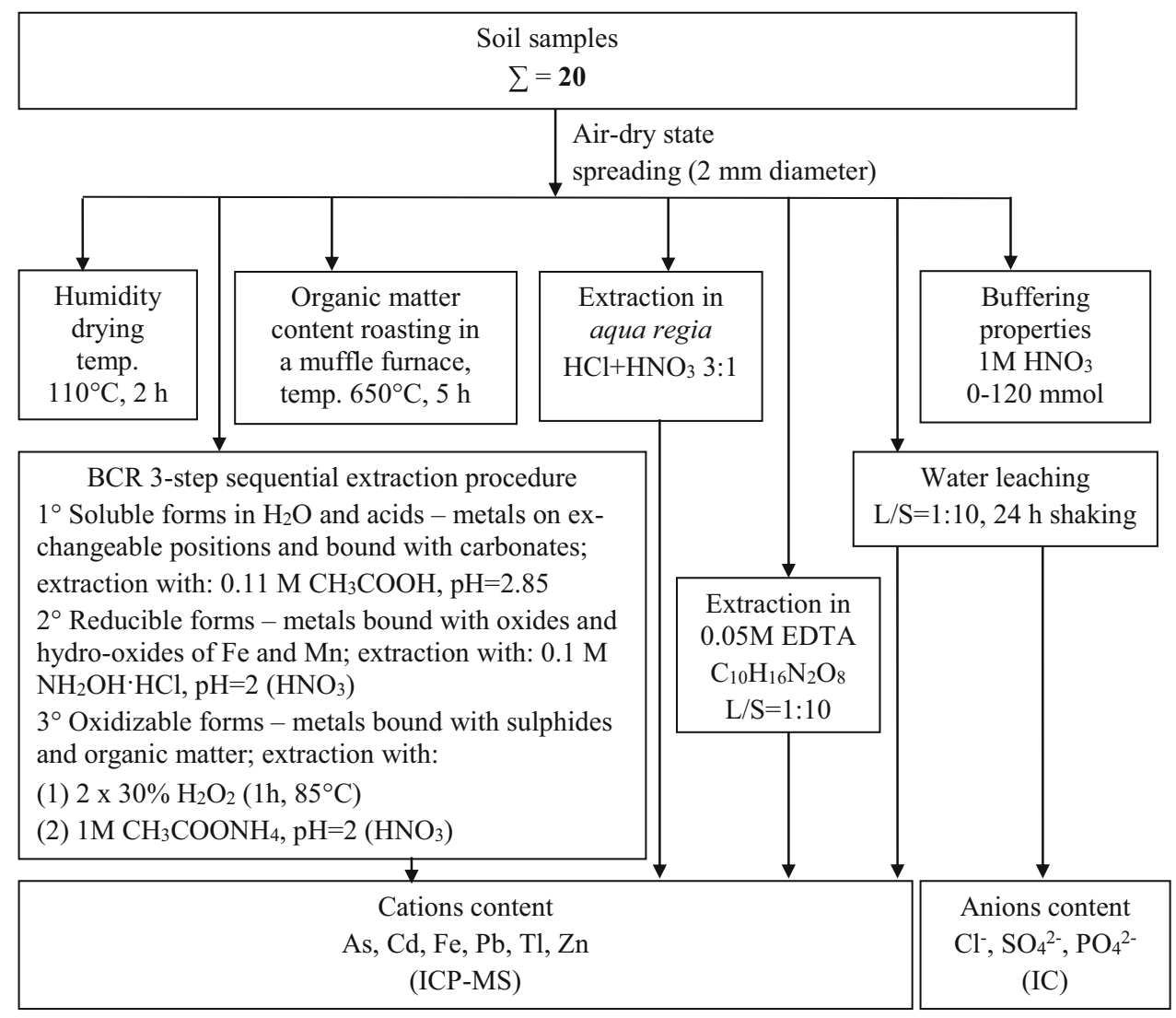

Fig. 2 Laboratory procedure diagram for soil samples

Table 2 Size terms of mineral fractions in soils

\begin{tabular}{lll}
\hline Abbreviation & Designation & Size range $(\mathrm{mm})$ \\
\hline VC & Very coarse & $2-1$ \\
C & Coarse & $1-0.5$ \\
M & Medium & $0.5-0.25$ \\
F & Fine & $0.25-0.125$ \\
VF & Very fine & $0.125-0.062$ \\
S & Silt & $<0.062$ \\
\hline
\end{tabular}

$\Phi=2-3)$ and $\mathrm{M}-$ medium ( $\Phi=1-2)$ with the prevalence of the $F$ fraction. Very fine $(0 . X-X \mathrm{~mm})$ flakes of biotite and potassium feldspar grains were rare. Quartz grains were matted and scratched, which was characteristic of the grains subjected to eolian transport.

- 10-20 cm bgl; $\mathrm{M}$ fraction grains strongly dominated and were accompanied by the $F$ fraction grains. The identified minerals included major quartz, minor feldspars, and biotite. The amount of broken plant fragments was higher than that in the previous sample.

- 20-30 cm bgl; this layer had a similar appearance to that of the overlay, except for a considerable content of compact aggregates composed of the VF and $S$ fraction grains.
- $\quad 30-40 \mathrm{~cm}$ bgl; $\mathrm{M}$ and $F$ fraction grains dominated. The mineral composition did not change in relation to the upper layers, with one exception: the presence of wellrounded garnet grains.

- $\quad 40-50 \mathrm{~cm} \mathrm{bgl} ; \mathrm{M}$ and $F$ fraction grains, with the same mineral composition as above; the brownish colour of the sample was slightly lighter.

- $50-60 \mathrm{~cm}$ bgl; the quartz grains were distinctly smaller (VF, $F$, and $\mathrm{M}$ fractions) than those in the upper layers, while the content of fine-psammitic grains increased (VF). Quartz grains showed good rounding. Feldspars and biotite were still present.

The soil sample from Site II was collected ca. $600 \mathrm{~m}$ $E$ of the flotation tailing dump of the ZGH "Bolesław" Mine. Its colour was brown to brownish. The soil was composed of the $C$-size grains (coarse fraction, size: $\Phi=0-1$ ), with a minor contribution of the M-size grains and a significantly lower proportion of the $F$ fraction. Mineral grains were well rounded and they contained mainly quartz ( $>50 \%$ ), milky-grey feldspars, and fine flakes of biotite, accompanied by bituminous coal fragments. A strong and rapid reaction with $\mathrm{HCl}$ indicated the presence of a small proportion of carbonates (probably the carbonate cement of mineral aggregates and/or dispersed 
calcite). In the soil profile collected in the same place, the soil colour distinctly changed with depth, from dark brown to very light brown. The reaction with $\mathrm{HCl}$ disappeared and the grain size distribution ranged from the prevalent $\mathrm{M}$ and $F$ fractions in the $0-10$ - and $10-20-\mathrm{cm}$ bgl intervals to the $F$ and VS fractions dominating below $20 \mathrm{~cm}$. The mineral composition within the whole profile included quartz, feldspars, and very fine-grained clay aggregates, supplemented occasionally by silver-white muscovite flake traces.

The soil sample from Site III, collected ca. $50 \mathrm{~m} \mathrm{~N}$ (north) of the ZGH "Bolesław" Mine, was dark brown and contained a high amount of fragmented plant material and clay minerals. The VF and $S$ grain fractions dominated, which significantly hindered further hand-specimen identification of mineral grains. Soil did not react with $\mathrm{HCl}$.

The soil sample from Site IV, collected ca. $750 \mathrm{~m} \mathrm{SE}$ (south east) of the ZGH "Bolesław" Mine, was brown to brownish. Dominating grains belonged to the $\mathrm{VC}, C$, and $\mathrm{M}$ fractions, with a low proportion of the $F$-size grains. The sample's $\mathrm{HCl}$ reaction was hardly visible. The mineral composition included quartz, feldspars (orthoclase feldspar was clearly identified) and a high proportion of fragmented plant material.

The mineral composition described above corresponded to major rock types occurring in the bedrock strata, namely Mesozoic dolomites, ankeritic dolomites and limestone (Cabała 2009); the ore-bearing rocks also contained clay minerals, represented mainly by montmorillonite, illite and kaolinite. Quartz with minor chalcedony and opal were derived mainly from the Tertiary and Quaternary sand deposits.

\section{Physical and Chemical Soil Properties}

\section{Topsoil Samples}

The organic matter $(\mathrm{OM})$ contents in the material collected in 2014 ranged from 1.7 to $6.6 \%$, thus classifying the soils as medium and weakly organic. The OM content of Sample I increased from $6.2 \%$ in 1994 to $6.5 \%$ in 2009 , with $6.6 \%$ in 2014. In Sample II, the OM content decreased from $8.6 \%$ in 1994 to $4.4 \%$ in 2009 , and further to $3.6 \%$ in 2014 . In Sample III, the OM content decreased from $8.8 \%$ in 1994 to $5.0 \%$ in 2014 . The most pronounced was the OM content decrease in Sample IV: from 6.4\% in 1994 to 1.7\% in 2014. The OM content differences between 1994 and 2014, calculated against the 1994 figures, amounted to ca. $60 \%$ in Sample II, $44 \%$ in Sample III and $73 \%$ in Sample IV. Such OM content decreases could be explained by wind erosion blowing off the light organic matter from topsoil. Such erosion was supported by the presence of numerous mineral grains, with matt and scratched surfaces (Turski 1971; Oades 1988).

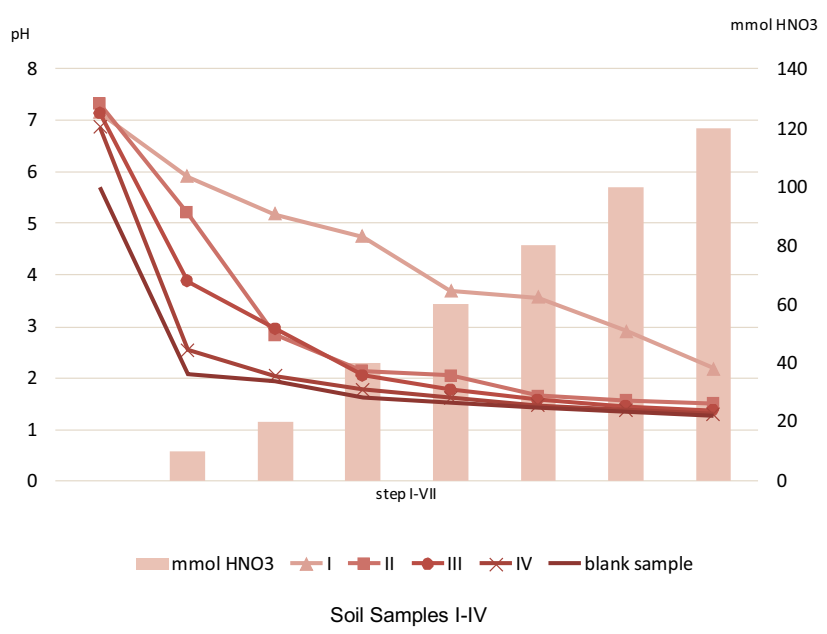

Fig. 3 Buffering properties of topsoil samples

The hydrolytic $\mathrm{pH}$ values ranged from 6.8 to 7.9 and those of the potential $\mathrm{pH}$ from 6.5 to 8.0 in the material collected in 2014. Consequently, the soil was classified either as neutral or occasionally as basic (Polish Standard $\mathrm{BN}-75 / 9180-03$ 1975). The values of the $\mathrm{pH}_{\mathrm{H}_{2} \mathrm{O}}$ and $\mathrm{pH}_{\mathrm{KCl}}$ have undergone only minor fluctuations over the period of 20 years. The $\mathrm{pH}_{\mathrm{H}_{2} \mathrm{O}}$ values of Site $\mathrm{I}$ amounted to 7.9 in 1994, 7.7 in 2009, and 7.4 in 2014; the $\mathrm{pH}_{\mathrm{KCl}}$ was constant at 7.8. The $\mathrm{pH}_{\mathrm{H}_{2} \mathrm{O}}$ values of Site II were also constant at 7.9 during the research period, whereas the $\mathrm{pH}_{\mathrm{KCl}}$ values increased from 7.3 in 2005 to 8.0 in 2014. At Site III, the $\mathrm{pH}_{\mathrm{H}_{2} \mathrm{O}}$ values were comparable: 7.0 in 1994 and 6.8 in 2014, and the same referred to the $\mathrm{pH}_{\mathrm{KCl}}$ values: 6.7 and 6.5 , respectively. At Site IV, the $\mathrm{pH}_{\mathrm{H}_{2} \mathrm{O}}$ value decrease was recorded from 7.6 in 1994 to 7.0 in 2014, with the decrease of the $\mathrm{pH}_{\mathrm{KCl}}$ values from 6.9 to 6.6 , respectively. Consequently, no significant changes occurred in the soil reaction over the last 20 years.

The investigations on the topsoil buffer properties indicated that the first portion of acid $\left(10 \mathrm{mmol}\right.$ of $\left.\mathrm{HNO}_{3}\right)$ considerably lowered pH. In Samples I, II, and III, the differences in $\Delta \mathrm{pH}$ values ranged from 1.2 to $3.3 \mathrm{pH}$ units, with the decrease by as many as $4.5 \mathrm{pH}$ units in Sample IV (Fig. 3). Further addition of nitric acid did not cause such high $\mathrm{pH}$ drops. The best buffer properties were found in Sample I: after treatment by $120 \mathrm{mmol} \mathrm{HNO}_{3}, \mathrm{pH}$ decreased from 7.2 to 2.2 , while after the same treatment, the $\mathrm{pH}$ values decreased from about 7.0 to 1.3 in the remaining samples.

\section{Soil Profiles}

The organic matter $(\mathrm{OM})$ content is one of the physicochemical soil parameters analysed in the present project. The respective values showed a regular decrease with the 
depth of the profiles. In Profile I, the OM content dropped from 6.6 to $1.5 \%$ in the $10-20-\mathrm{cm}$ interval, slightly increased to $2.8 \%$ within the $20-30-\mathrm{cm}$ range, and continued to drop to $1.4 \%$ in the $50-60-\mathrm{cm}$ interval. In Profile II, the OM content decreased from 3.6 to $0.5 \%$ in the $10-20-\mathrm{cm}$ interval and to $0.2 \%$ in the $50-60-\mathrm{cm}$ interval. The OM values measured in the 2009 profiles did not show any dissimilarities from the 2014 results. The organic matter enrichment at certain depths may have been caused by the anthropogenic transformations of some areas that affected the distribution of organic matter within soil profiles. Such processes could be controlled by the content and inventory of mineral components and their physico-chemical properties in specific profiles (Huot et al. 2014).

The $\mathrm{pH}$ values measured in 2014 showed a slight decreasing trend with the profile depth and that classified the soils as neutral. In Profile I, the $\mathrm{pH}_{\mathrm{H}_{2} \mathrm{O}}$ values systematically decreased from 7.4 in topsoil to 6.9 in the 50-60$\mathrm{cm}$ interval, while the corresponding $\mathrm{pH}_{\mathrm{KCl}}$ values decreased from 7.8 to 6.9. In Profile II, the $\mathrm{pH}_{\mathrm{H}_{2} \mathrm{O}}$ values also decreased, from 7.9 in topsoil to 6.9 in the $50-60-\mathrm{cm}$ interval, while the corresponding $\mathrm{pH}_{\mathrm{KCl}}$ values decreased from 8.0 to 6.6 .

The soil samples collected from all the depth intervals showed significant $\mathrm{pH}$ decreases (by 3-4 $\mathrm{pH}$ units) after the addition of the first portion of nitric acid (Fig. 4). Subsequent portions of nitric acid also caused $\mathrm{pH}$ decreases but never as high as the initial ones. Similar to topsoil, the soil profiles also represented poor buffer properties.

\section{Total Selected Metal Contents and Forms of Metal Binding in Topsoil}

The total metal content, determined after leaching the soil samples with aqua regia, was the highest in the soil collected at sampling Site I (SD standard deviation): $443 \mathrm{mg} /$ $\mathrm{kg}$ of As (SD $0.5 \mathrm{mg} / \mathrm{kg}$ ), $63.8 \mathrm{mg} / \mathrm{kg}$ of Cd (SD $0.44 \mathrm{mg} /$ $\mathrm{kg}$ ), $5121 \mathrm{mg} / \mathrm{kg}$ of $\mathrm{Pb}$ (SD $20.2 \mathrm{mg} / \mathrm{kg}$ ), $13.5 \mathrm{mg} / \mathrm{kg}$ of Tl (SD $0.23 \mathrm{mg} / \mathrm{kg}$ ), and $4.2 \mathrm{wt} \%$ of Fe (SD $226.3 \mathrm{mg} / \mathrm{kg}$ ). The soil sample collected at Site II represented twice lower metal contents; the same referred to $\mathrm{Cd}$ and $\mathrm{Zn}$ contents at Site III, with even lower $\mathrm{As}, \mathrm{Fe}, \mathrm{Pb}$, and $\mathrm{Tl}$ content differences. The lowest metal contents were found at Site IV (Fig. 5). A comparison of those results to the natural geochemical background (Kabata-Pendias and Pendias 1999) and the permissible values for $C$ type ground, i.e. those determined for industrial areas in the Regulation of the Minister of the Environment on soil and ground quality standards (RMŚ 2002), revealed that the permissible values were exceeded about 3-4 times for $\mathrm{Cd}, 2-8$ times for $\mathrm{Pb}$, and 5-8 times for $\mathrm{Zn}$. The degree of soil contamination with $\mathrm{As}, \mathrm{Fe}$, and $\mathrm{Tl}$ could not be determined, because the respective data were not specified in RMŚ 2002. The contents determined by the authors also exceed the permissible soil limits of metals recommended by the WHO (in $\mathrm{mg} / \mathrm{kg}$ ): 0.35 for $\mathrm{Cd}, 30$ for $\mathrm{Cu}, 35$ for $\mathrm{Pb}$, and 90 for $\mathrm{Zn}$ (Tembo et al. 2006). Consequently, the mean content of $\mathrm{Cd}$ in topsoil was exceeded more than 100 times, and that of $\mathrm{Pb}$ and $\mathrm{Zn}$ more than 60 times. The highest excesses occurred in Sample I: Cd 182 times, $\mathrm{Pb} 146$ times, and $\mathrm{Zn}$ 90 times. Such amounts of $\mathrm{Cd}, \mathrm{Pb}$, and $\mathrm{Zn}$ indicated very high contamination of the area soil, classifying it in the most polluted soil Group 3 (Rodríguez et al. 2009). Only Sample IV was assigned to Group 2, considering a slightly lower $\mathrm{Pb}$ amount (Table 3).

A comparison of the total metal contents determined in topsoil in 2014 with the data obtained in 1994 (KicińskaŚwiderska 1999), 2005 (Gruszecka 2011), and 2009 (Gruszecka and Wdowin 2013) indicated significant content drops in the 20-year period. Significant drops were found in Samples III and IV, with lower ones (except for $\mathrm{Fe}, \mathrm{Tl}$, and $\mathrm{Zn}$ ) in Sample II. Sample I was an exception. The content values of $\mathrm{As}, \mathrm{Cd}$, and $\mathrm{Pb}$ increased there by about 110,28 , and $125 \%$, respectively. The $\mathrm{Fe}$ amounts were stable between 1994 and 2014.

Another parameter calculated for all the metals was the contamination factor CF (Liu et al. 2005). Despite the above-mentioned drops during over 20 years, the CF values exceeded from several to several hundred times the value of 6 , which indicated a very strong contamination. The highest $\mathrm{CF}$ values were identified for $\mathrm{Cd}, \mathrm{Pb}$, and $\mathrm{Zn}$, determined at 185, 132 and 126, respectively, in 2014.

Considering the significant soil pollution with $\mathrm{Pb}, \mathrm{Zn}$, and $\mathrm{Cd}$, another parameter was calculated, namely the contamination index $S$ (Trafas et al. 1990). Its figures $<2$ characterized the areas with metal contents below the permitted values, while those $>5$ indicated highly contaminated soil. The mean value of the total contamination index $S$ of the local topsoil was 194 (calculated from the total $\mathrm{Zn}, \mathrm{Pb}$, and $\mathrm{Cd}$ contents for all the four sampling sites), as obtained from the 1994 data, or 52 as obtained from the 2014 data, indicating nearly fourfold decrease. The highest $S$ index, exceeding 110 in 2014, was determined for Site I. Consequently, the results showed a nearly fourfold decrease of the total pollution of the area soil with $\mathrm{Cd}, \mathrm{Pb}$, and $\mathrm{Zn}$ over the 20 -year period and indicated high topsoil pollution levels.

Yet another parameter, the pollution load index (PLI) (Liu et al., 2005), led to similar conclusions. PLI $=1$ corresponds to the metal content approximating the geochemical background, while the values exceeding one (PLI $>1$ ) are pollution markers (Cabrera et al. 1999). PLI calculated on the basis of the 2014 topsoil data amounted to 226 and 556 in reference to the 1994 data, still indicating strong soil pollution. 
Soil Profile I

depth $[\mathrm{cm}]$
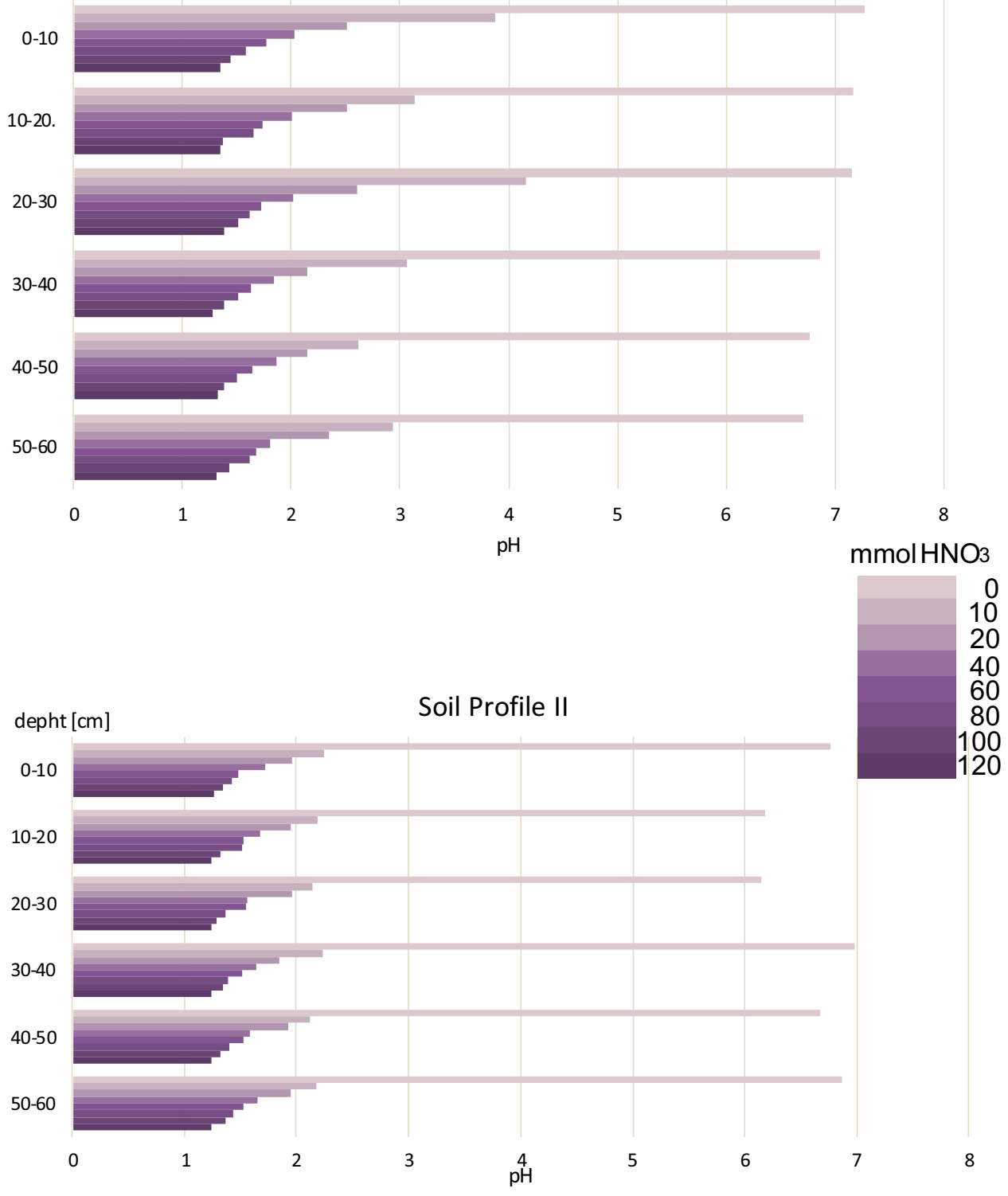

Fig. 4 Buffering properties of soil profile samples

The BCR three-step sequential extraction procedure revealed that the amount of cations bound to various compounds (or forms) in soil was not uniform (Fig. 6). The exchangeable positions (Step I, see Fig. 2) contained $30-83 \%$ of $\mathrm{Cd}$ and from above 20 to above $60 \%$ of $\mathrm{Zn}$ in comparison to total metal contents. With regard to $\mathrm{Pb}$, its exchangeable (mobile) proportion reached above $60 \%$ of total metal content in Sample I and 30\% in Sample II, without exceeding $10 \%$ in Samples III and IV. As, Fe, and $\mathrm{Tl}$ were associated mainly with the crystalline structure of minerals or with hardly mobile elements in soil. The easily mobile Cd was $83 \%$ of total metal content
$(53 \mathrm{mg} / \mathrm{kg}$ ) in the topsoil of the Site I and $73 \%(33 \mathrm{mg} /$ $\mathrm{kg}$ ) in the topsoil of the Site III. Soil collected from Site II displayed the proportion of exchangeable $\mathrm{Cd}$ exceeding $30 \%(12 \mathrm{mg} / \mathrm{kg})$, and more than $60 \%$ in the extraction residuum. In soil Sample IV, cadmium occurred in the first three extraction steps and it was not present in residuum. The majority of cadmium, about $48 \%$, concentrated in oxidized forms (Step III of the BCR procedure). The proportions of the exchangeable $\mathrm{Pb}$ and $\mathrm{Zn}$ were significant: $60 \%$ of $\mathrm{Pb}(0.3 \mathrm{wt} \%)$ and $66 \%$ of $\mathrm{Zn}$ $(0.5 \mathrm{wt} \%)$ in Sample I and $31 \%$ of $\mathrm{Pb}(532 \mathrm{mg} / \mathrm{kg})$ and $26 \%$ of $\mathrm{Zn}(0.14 \mathrm{wt} \%)$ in Sample II. The high proportion 
(a)

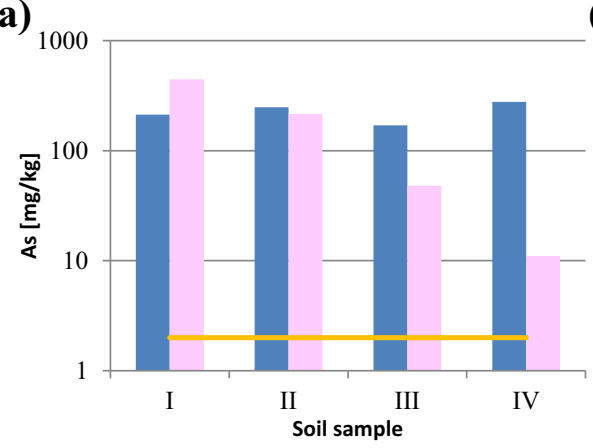

(c)

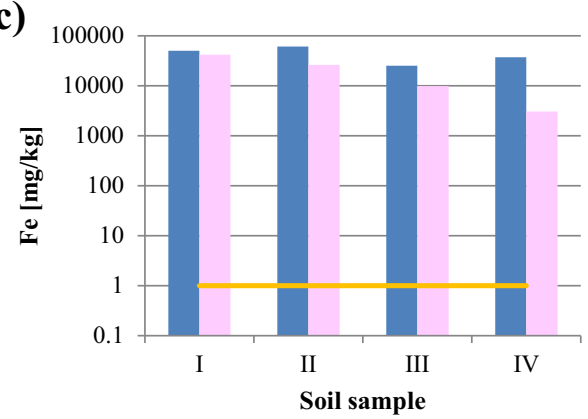

(e)

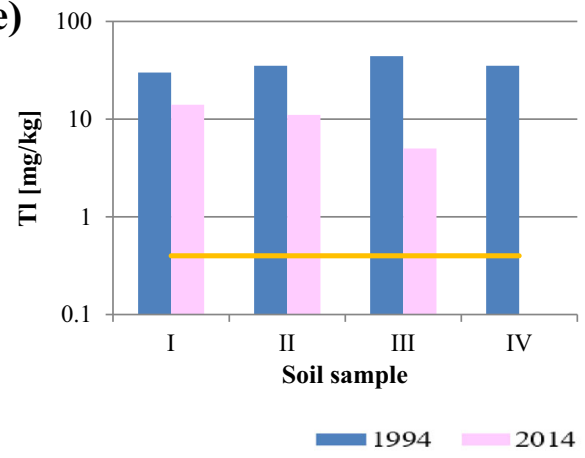

(b)

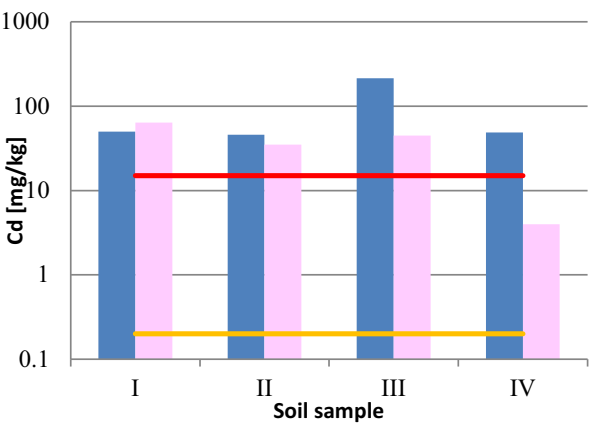

(d)

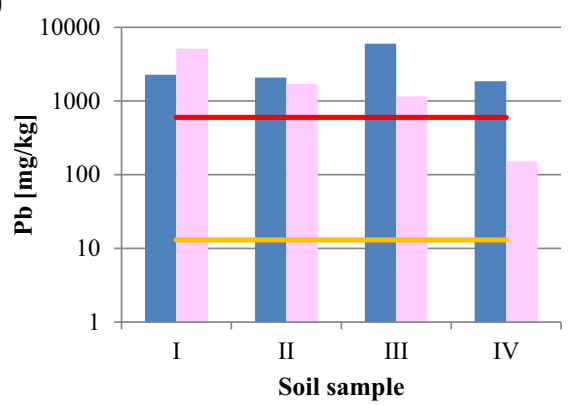

(f)

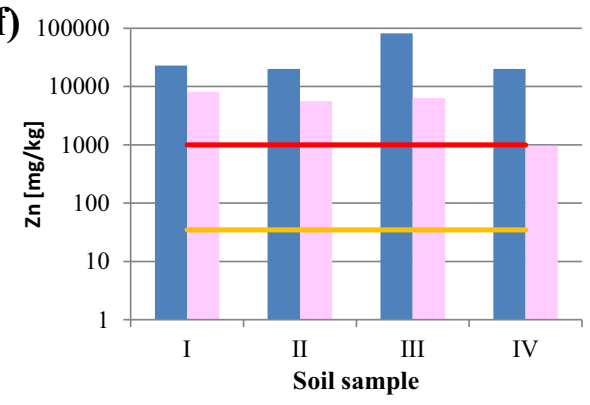

Fig. 5 Total concentration of analysed metals in topsoil samples: a As, b $\mathrm{Cd}, \mathbf{c} \mathrm{Fe}, \mathbf{d ~ P b}, \mathbf{e} \mathrm{Tl}, \mathbf{f} \mathrm{Zn}$ (G.B.- geochemical background after Kabata-Pendias and Pendias 1999, Ground C-RMŚ 2002)

Table 3 Criteria for soil classification by total metal content (after Rodríguez et al. 2009)

\begin{tabular}{lllll}
\hline Metal & Unit & $\begin{array}{l}\text { Group 1 } \\
\text { Background levels in sandy soils } \\
\text { (Kabata-Pendias and Pendias } \\
\text { 2000) }\end{array}$ & $\begin{array}{l}\text { Group 2 } \\
\text { Background levels to maximum allowable concentrations of heavy } \\
\text { metals for agricultural soils from European Directive 86/278/EEC } \\
\text { (Council of the European Communities 1986) }\end{array}$ & $\begin{array}{l}\text { Group 3 } \\
>\text { Maximum } \\
\text { allowable } \\
\text { concentrations }\end{array}$ \\
\hline $\mathrm{Cd}$ & $\mathrm{mg} / \mathrm{kg}$ & $0.01-2.7$ & $2.7-3$ & $>3$ \\
$\mathrm{~Pb}$ & $2.3-70$ & $70-300$ & $>300$ \\
$\mathrm{Zn}$ & $3.5-220$ & $220-300$ & $>300$ \\
\hline
\end{tabular}

of $68 \% \mathrm{Zn}$ content in residuum was remarkable. The distribution of $\mathrm{Pb}$ varied strikingly: $\mathrm{Pb}$ was associated mainly with the reducible phases $(72 \%$ of total metal content) in Sample III and with the oxidized ones $(87 \%)$ in Sample IV. Most of topsoil arsenic was found in the extraction residuum. Thallium was mainly associated with the oxidized phases and the extraction residuum, except for Sample III in which the proportion of the oxidized phases was $52 \%$ of $\mathrm{Tl}$ and that of exchangeable phases $26 \%$ of $\mathrm{Tl}$. Iron was bound mainly to the oxidized phases and/or residuum.

A comparison of the proportions of various forms of metal binding determined in topsoil in 2014 with the data obtained in 1994 (Kicińska-Świderska 1999), 2005 
(a)

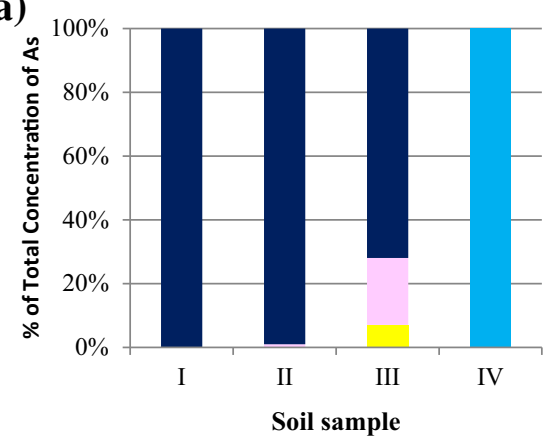

(d)

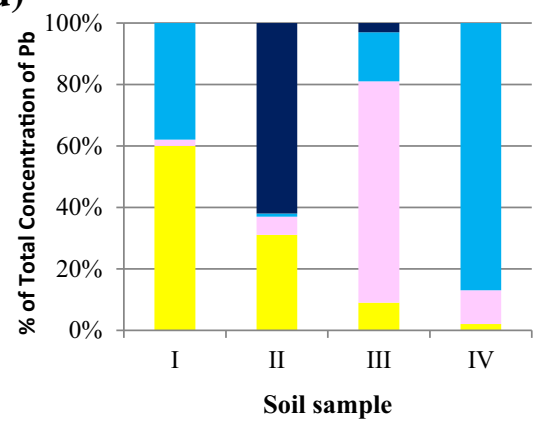

(b)

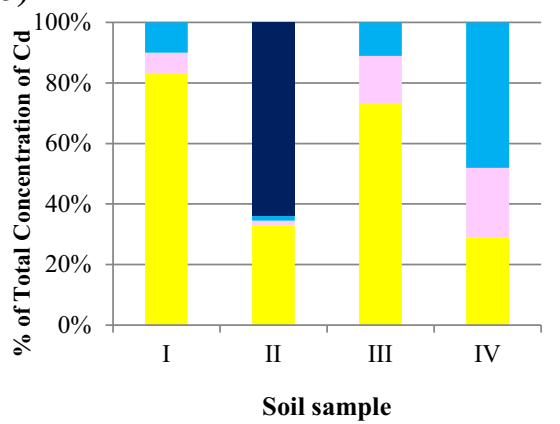

(e)

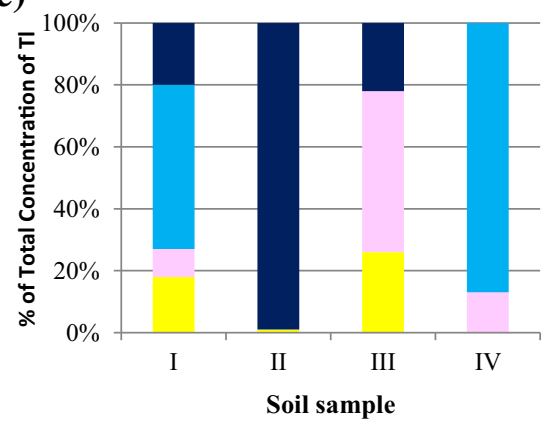

(c)

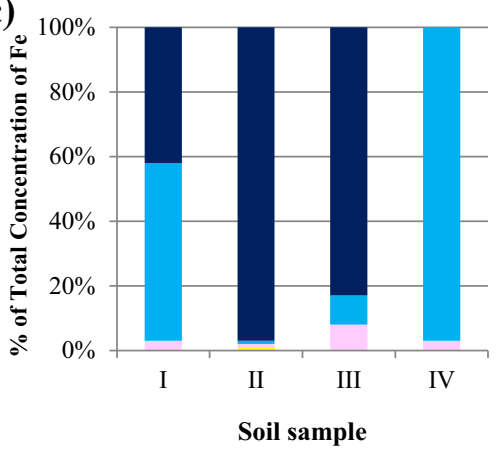

(f)

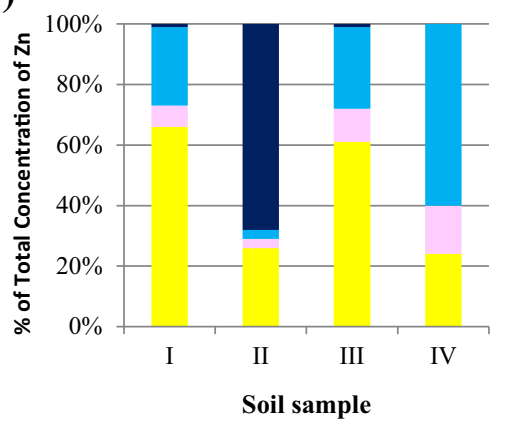

acidextractable $\square$ reducible $\|$ oxidisable $\square$ residue

Fig. 6 Binding forms of metals (BCR procedure) as a \% of total concentration in topsoil samples: a $\mathrm{As}, \mathbf{b ~ C d}, \mathbf{c} \mathrm{Fe}, \mathbf{d ~ P b}, \mathbf{e ~ T l , ~} \mathrm{Zn}$

(Gruszecka 2011) and 2009 (Gruszecka and Wdowin 2013) in Sample I showed a significant increase of the easily mobile Cd from 43 to $83 \%$ of total metal content, with $\mathrm{Pb}$ from 35 to $60 \%$, and $\mathrm{Zn}$ from 55 to $66 \%$, whereas in Sample II, the proportions of such mobile forms decreased: $\mathrm{Cd}$ from 67 to $33 \%, \mathrm{~Pb}$ from 45 to $31 \%$, and $\mathrm{Zn}$ from 70 to $26 \%$. The picture was more complex in Samples III and IV: the proportions of the mobile forms of $\mathrm{Zn}$ increased from 55 to $61 \%$ and from 14 to $24 \%$, but the proportions of the mobile $\mathrm{Pb}$ forms decreased from 47 to $9 \%$ and from 25 to $2 \%$. In Sample IV, cadmium showed a distinct decrease of its proportion, from 58 to $29 \%$.

\section{Total Selected Metal Contents and their Forms of Binding in Soil Profiles}

Considering the above-mentioned data, the examination of vertical distribution, binding types, and potential bioavailability concerned the soil samples collected at Sites I and II since their metal contents were the highest.

In the soil profile extracted from Site I, the highest total metal content occurred in the $20-30-\mathrm{cm}$ interval as follows (in $\mathrm{mg} / \mathrm{kg}$ ) (SD standard deviation): 53.1 for As (SD $0.64 \mathrm{mg} / \mathrm{kg}$ ), 7.95 for $\mathrm{Cd}$ (SD $0.013 \mathrm{mg} / \mathrm{kg}$ ), 7882 for $\mathrm{Fe}$ (SD $50.2 \mathrm{mg} / \mathrm{kg}$ ), 520 for $\mathrm{Pb}$ (SD $0.74 \mathrm{mg} / \mathrm{kg}$ ), 1.78 for $\mathrm{Tl}$ (SD $0.16 \mathrm{mg} / \mathrm{kg}$ ), and 1198 for $\mathrm{Zn}$ (SD $8.45 \mathrm{mg} / \mathrm{kg}$ )
(Fig. 7), and matched those of the $0-10-\mathrm{cm}$ interval. In the soil profile extracted from Site II, the highest contents of $\mathrm{Pb}(31.0 \mathrm{mg} / \mathrm{kg}, \quad \mathrm{SD} 0.17 \mathrm{mg} / \mathrm{kg}), \mathrm{Zn}(236 \mathrm{mg} / \mathrm{kg}$, SD $0.86 \mathrm{mg} / \mathrm{kg})$, and $\mathrm{Cd}(1.57 \mathrm{mg} / \mathrm{kg}$, SD $0.009 \mathrm{mg} / \mathrm{kg})$ also occurred in the $0-10-\mathrm{cm}$ interval, while the concentrations of $\mathrm{Fe}(1345 \mathrm{mg} / \mathrm{kg}, \mathrm{SD} 10.7 \mathrm{mg} / \mathrm{kg})$ in the $10-20-\mathrm{cm}$ interval. Below the $20-30-\mathrm{cm}$ interval, the metal contents decreased with depth in both profiles.

The proportions of the fractions separated by the BCR procedure, which bind metals in soil, were diversified (Fig. 8). As it was already described for topsoil, $\mathrm{Cd}, \mathrm{Zn}$, and $\mathrm{Pb}$ were associated mainly with the most mobile forms. In Profile I, the exchangeable forms (BCR procedure Step I) containing $\mathrm{Cd}$ and $\mathrm{Zn}$ dominated: the proportion of $\mathrm{Cd}$ was $61-76 \%$ of total metal content and that of $\mathrm{Zn} 57-72 \%$. Lead was associated mainly with BCR procedure Step II: its proportion equalled $37-56 \%$, with $55-83 \%$ of Fe in Step III and 40-50\% in Steps III and IV. Arsenic remained mainly within the crystalline lattice, and it was present in reduced forms (35\%) only in the $20-30-\mathrm{cm}$ interval. Thallium followed the trend of arsenic and occurred either in hardly soluble forms and/or it was in-built into the crystalline lattice. Only in the 20-30- and 30-40-cm intervals, $\mathrm{Tl}$ occurred in easily soluble forms (BCR procedure Steps I and II), with its proportion reaching $20 \%$ of total metal content. In Profile II, cadmium occurred mainly 

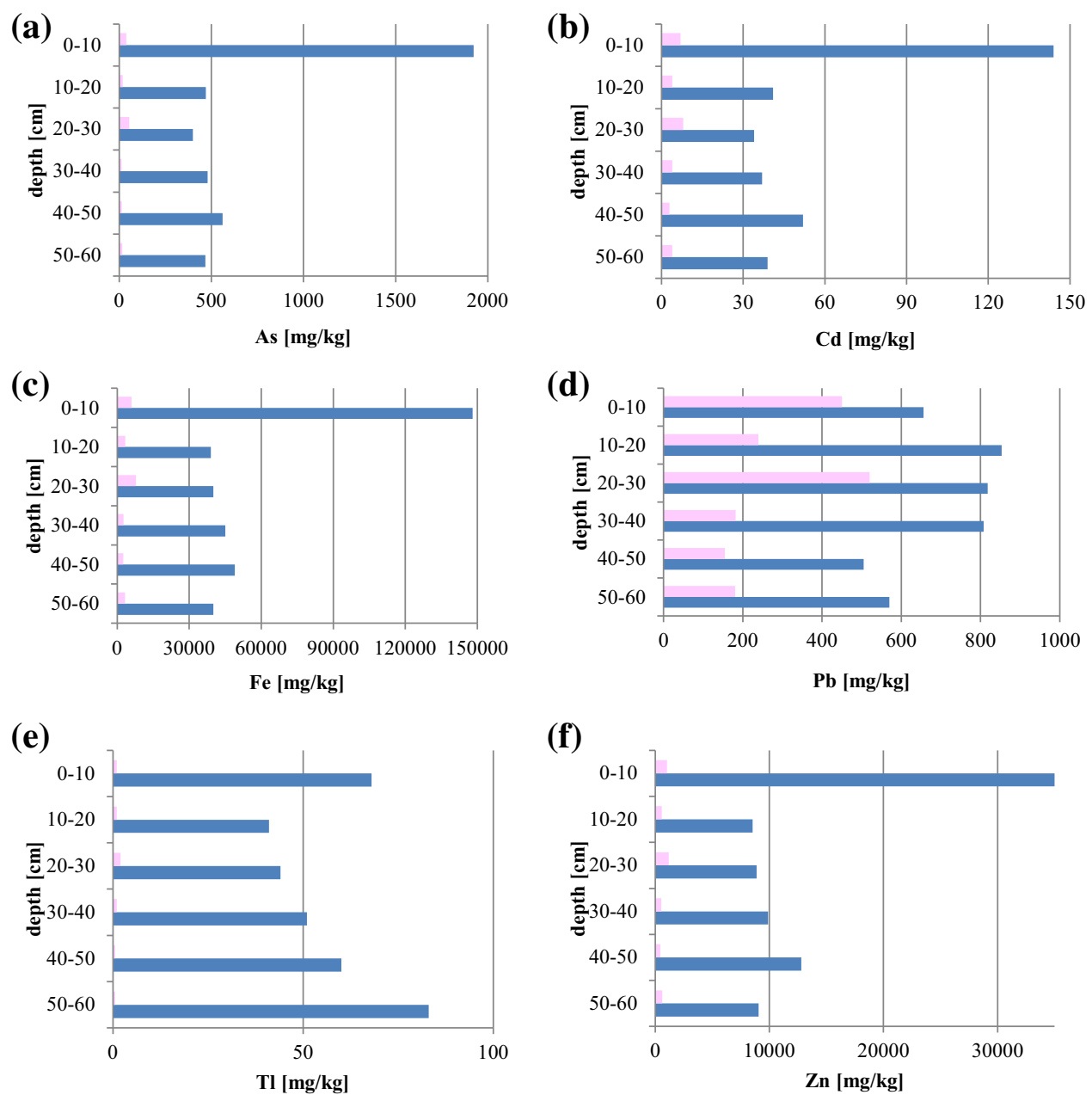

$\square 1994 \square 2014$

Fig. 7 Total concentration of analysed metals in the soil profiles from Site I: a As, b Cd, c Fe, d Pb, e Tl, f Zn

in mobile forms (BCR procedure Step I), with a 38-82\% proportion, and in residuum. Lead in soil Profile II $(15-74 \%)$ was bound mainly to the crystalline lattice and it occurred in reduced forms (21-64\%). Zinc was mainly associated with the residual BCR procedure Step I (43-73\%), although only in the $0-10-\mathrm{cm}$ interval the proportion of exchangeable forms of Step I dominated (69\%), while the proportion of that in Step III was as low as $16 \%$. Arsenic wholly remained in the extraction residuum, except for the $0-10-\mathrm{cm}$ interval, in which $12 \%$ of As was associated with Step III. Iron was present mainly in hardly soluble forms (share $75-96 \%$ of total metal content) and the proportions of remaining forms reached single-digit values only.

\section{Anion Content in Water Solutions of Soil}

All water solutions of topsoil contained chlorides and sulphates, ranging from 2.06 to $4.93 \mathrm{mg} / \mathrm{dm}^{3}$ for chlorides and from 0.048 to $14.6 \mathrm{mg} / \mathrm{dm}^{3}$ for sulphates (Fig. 9). Chloride concentrations were high in Samples III and IV, while those of sulphates in Sample I. Nitrates $(1.90 \mathrm{mg} /$ $\mathrm{dm}^{3}$ ) were found only in Sample II, whereas phosphates $\left(0.081\right.$ and $\left.0.001 \mathrm{mg} / \mathrm{dm}^{3}\right)$ in Samples III and IV, respectively.

The vertical distribution of $\mathrm{Cl}^{-}$in the water solutions of the samples collected in 2014 revealed an increase of chlorides from the surface to the $20-30-\mathrm{cm}$ interval, ranging from 11.9 to 25.9 in Profile $\mathrm{I}$ and from 5.35 to $7.40 \mathrm{mg} / \mathrm{dm}^{3}$ in Profile II (Fig. 10). With depth, the concentrations of $\mathrm{Cl}^{-}$decreased from 6.58 to $4.11 \mathrm{mg} / \mathrm{dm}^{3}$ in Profile I and from 6.58 to $0.82 \mathrm{mg} / \mathrm{dm}^{3}$ in Profile II. The concentrations of $\mathrm{SO}_{4}{ }^{2-}$ were on increase in Profile I but on decrease in Profile II.

The concentration of phosphate anions in Profile I increased with depth, and, in Profile II, equalled $0.009 \mathrm{mg}$ of $\mathrm{PO}_{4}{ }^{3-} / \mathrm{dm}^{3}$ in the $0-10-\mathrm{cm}$ soil interval and $0.05 \mathrm{mg}$ of $\mathrm{PO}_{4}{ }^{3-} / \mathrm{dm}^{3}$ in the $10-20-\mathrm{cm}$ interval bgl. Nitrates were 

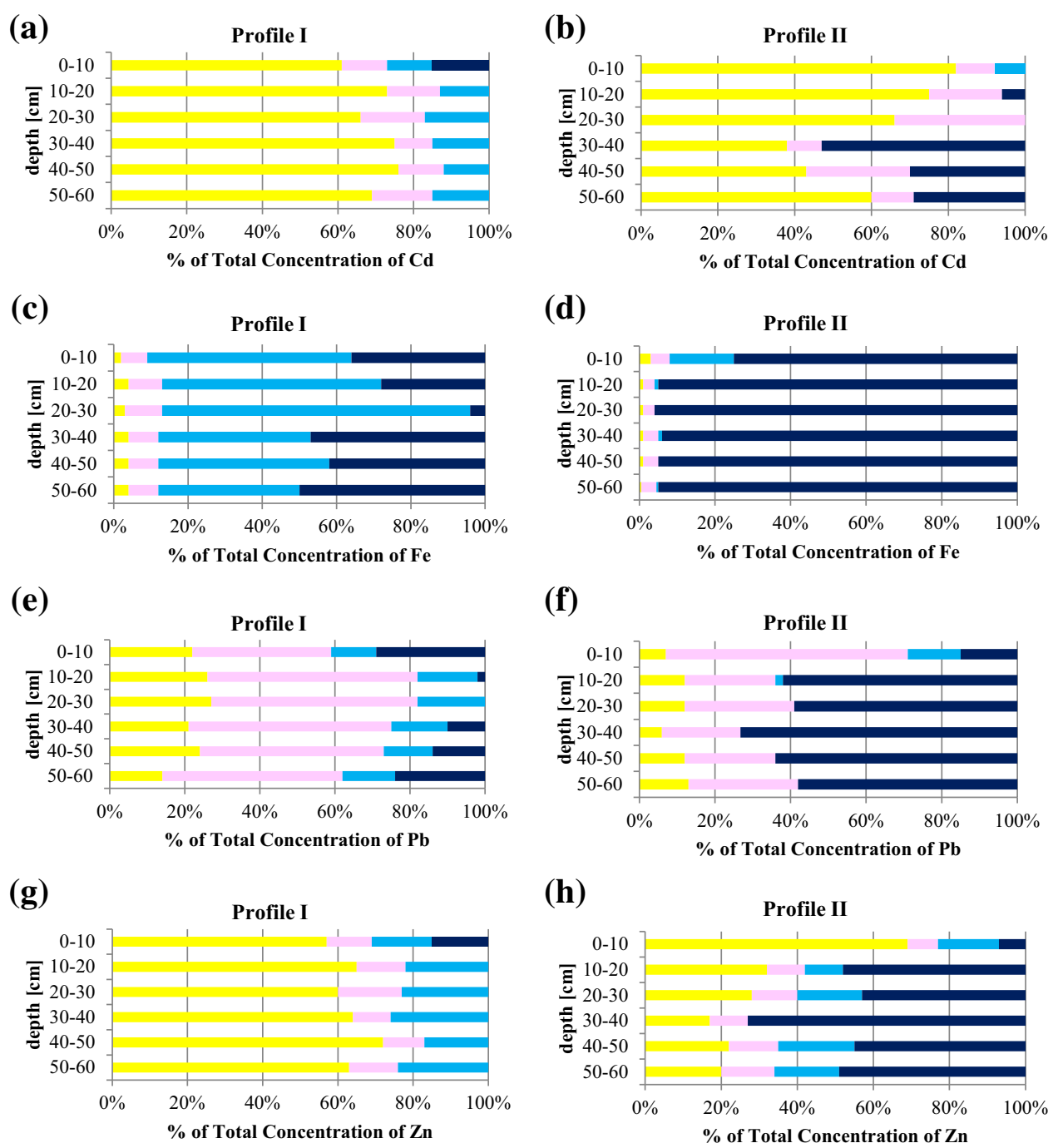

acidextractable reducible $\square$ oxidisable $\mathbf{m}$ residue

Fig. 8 Binding forms of metals (BCR procedure) as a \% of total concentration in soil profiles: a, b Cd; c, d Fe; e, f Pb; $\mathbf{g}, \mathbf{h} \mathrm{Zn}$

found in the concentrations above the detection limit in Profile I and only in one more interval, i.e. $40-50 \mathrm{~cm} \mathrm{bgl}$ (1.00 $\mathrm{mg}$ of $\left.\mathrm{NO}_{3}{ }^{-} / \mathrm{m}^{3}\right)$, and in two intervals: $10-20 \mathrm{~cm}$ $\left(0.60 \mathrm{mg} \mathrm{NO}_{3}{ }^{-} / \mathrm{dm}^{3}\right)$ and $20-30 \mathrm{~cm}\left(1.40 \mathrm{mg} \mathrm{NO}_{3}{ }^{-} / \mathrm{dm}^{3}\right)$ in Profile II.

The concentrations of $\mathrm{Cl}^{-}$pointed at its anthropogenic origin, associated with winter road salting. Also anthropogenic origin was displayed by the concentrations of $\mathrm{SO}_{4}{ }^{2-}$ in the topsoil of Profiles I and II, where their presence, explained by the mining and processing activities of sulphide ores in the Olkusz area, was rather obvious. It should be stressed that the vertical $\mathrm{Cl}^{-}$and $\mathrm{SO}_{4}{ }^{2-}$ concentrations poorly corresponded with those determined in the respective topsoil samples. With respect to $\mathrm{PO}_{4}{ }^{3-}$ and $\mathrm{NO}_{3}{ }^{-}$, no reliable conclusions could be drawn, as the concentrations of the two anions oscillated around the detection limits.

\section{Bioavailability of Metals in the Olkusz Area Soils}

Lead was the metal with the highest bioavailability to plants (soil extraction with the 0.05 M EDTA; KabataPendias et al. 1993), as its proportion in easily fixable forms amounted to $72-80 \%$ of total metal content. Besides, Cd was also easily available for plants: the plant fixable forms bound $30-70 \%$ of $\mathrm{Cd}$. In case of $\mathrm{Zn}, 24-44 \%$ of total metal content was potentially bioavailable (Fig. 11). Below, we specified the highest contents and the corresponding proportions of bioavailable metals: Soil II: $32 \mathrm{mg}$ of $\mathrm{Cd} / \mathrm{kg}$ (70\%); Soil I: $3931 \mathrm{mg}$ of $\mathrm{Pb} / \mathrm{kg}$ (77\%); Soil IV: 

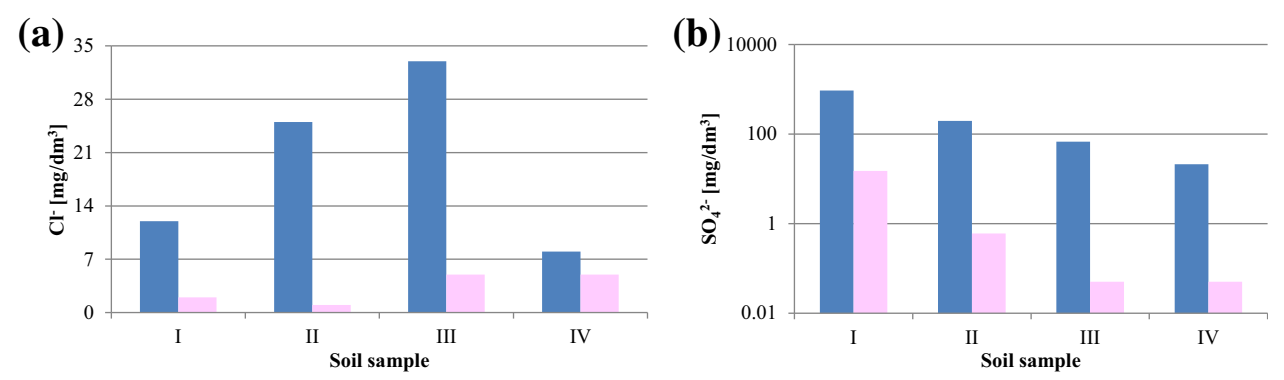

$\square 1994=2014$

Fig. 9 Concentrations of $\mathbf{a ~} \mathrm{Cl}^{-}$and $\mathbf{b ~ \mathrm { SO } _ { 4 }}{ }^{2-}$ in water leachates of topsoil samples
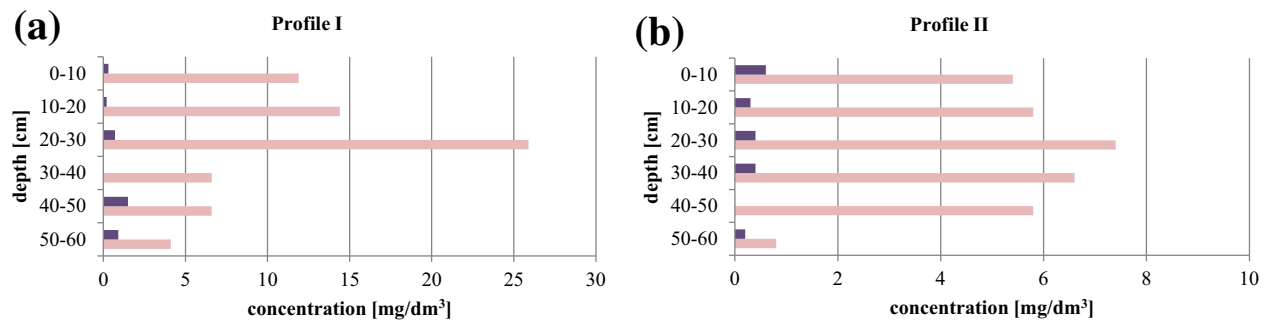

$=\mathrm{Cl}^{-} \quad-\mathrm{SO}_{4}^{2-}$

Fig. 10 Concentrations of $\mathrm{Cl}^{-}$and $\mathrm{SO}_{4}{ }^{2-}$ in water leachates of a soil profile I and $\mathbf{b}$ soil profile II

$14.9 \mathrm{mg}$ of $\mathrm{As} / \mathrm{kg}(31 \%), 603 \mathrm{mg}$ of $\mathrm{Fe} / \mathrm{kg}(6 \%), 0.6 \mathrm{mg}$ of $\mathrm{Tl} / \mathrm{kg}(13 \%)$, and $3345 \mathrm{mg}$ of $\mathrm{Zn} / \mathrm{kg}$ (53\% of total metal content).

A comparison of those results with the ones obtained in 1994 (Kicińska-Świderska 1999) indicated that the proportion of easily fixable forms containing $\mathrm{Zn}$ significantly increased (even up to $40 \%$ of total metal content) over the last two decades, which was also marked by the $\mathrm{Pb}$ - and Cd-bearing forms.

The amounts of metals extracted by the EDTA solution from the vertical soil profiles collected in 2014 were diversified, although they corresponded to topsoil data. In soil Profile I, the proportions of $\mathrm{Cd}, \mathrm{Zn}$, and $\mathrm{Pb}$ in bioavailable forms oscillated between 60 and $70 \%$ of total metal content, but were much lower in Profile II: $\mathrm{Cd}$ at ca. $30, \mathrm{~Pb}$ at ca. 20 , and $\mathrm{Zn}$ at ca. $40 \%$. In the case of Fe, the proportions of its bioavailable forms were rather stable in both profiles and oscillated within the range of several percents of total metal content (Fig. 12). In Profile I, the extracted amounts (being potentially bioavailable for plants) were as follows: $\mathrm{Cd}$ from 1.9 to $4.7 \mathrm{mg} / \mathrm{kg}$ (equivalent of 59-77\% of total metal content), $\mathrm{Pb}$ from 77 to $269 \mathrm{mg} / \mathrm{kg}$ (43-68\%), $\mathrm{Zn}$ from 273 to $603 \mathrm{mg} / \mathrm{kg}$ (50-61\%), Fe from 167 to $333 \mathrm{mg} / \mathrm{kg}$ (4-7\%), and As from 0.35 to $1.0 \mathrm{mg} / \mathrm{kg}(1-5 \%)$. In Profile II, the extracted amounts were as follows: $\mathrm{Cd}$ from 0.02 to $0.9 \mathrm{mg} / \mathrm{kg}$ (equivalent of $27-57 \%$ ), $\mathrm{Pb}$ from 4.4 to $7.6 \mathrm{mg} / \mathrm{kg}$ (34-45\%), $\mathrm{Zn}$ from 4.1 to $101 \mathrm{mg} / \mathrm{kg}(13-43 \%)$ and $\mathrm{Fe}$ from 7.9 to $39 \mathrm{mg} / \mathrm{kg}(1-3 \%)$.

The amounts of metals extracted with distilled water (water leaching) from topsoil and soils collected from the profiles were low. As to topsoil, water extracts carried only $\leq 1 \%$ of the total figures for (or the proportions of) $\mathrm{Cd}, \mathrm{Pb}$, and $\mathrm{Zn}$, while the same proportions of $\mathrm{Fe}$ and As were found only in Samples III and IV. As to soils of Profile I, water extracts carried only $\leq 2 \%$ of the total figures for $\mathrm{Cd}$ and $\mathrm{Zn}$ and $\leq 1 \%$ of $\mathrm{Pb}, \mathrm{As}$, and $\mathrm{Fe}$. As to soil Profile II, it was possible to extract $\leq 6 \%$ of $\mathrm{Cd}$ and $\leq 2 \%$ of $\mathrm{Pb}, \mathrm{Zn}$, and Fe.

\section{Assessment of Potential Environmental Risks}

Since the soils contained significant amounts of metals, their analyses were supplemented by a determination of the potential environmental risk, using the RAC coefficient. The coefficient was calculated based on two types of metal contents: metals in exchangeable forms and those associated with carbonates (Rodríguez et al. 2009). The total figures of those two values described the risk ranging from low to very high in a five-degree scale (Table 4). The RAC coefficient was calculated from the amounts of metals determined in BCR procedure Step I in 2014. The highest 
(a)

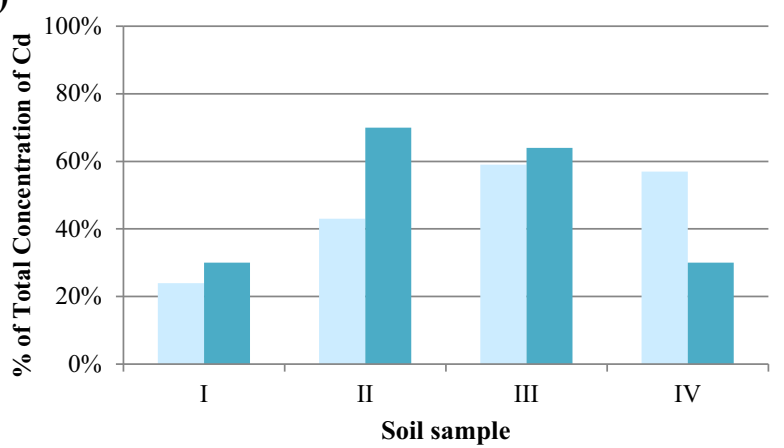

(b)

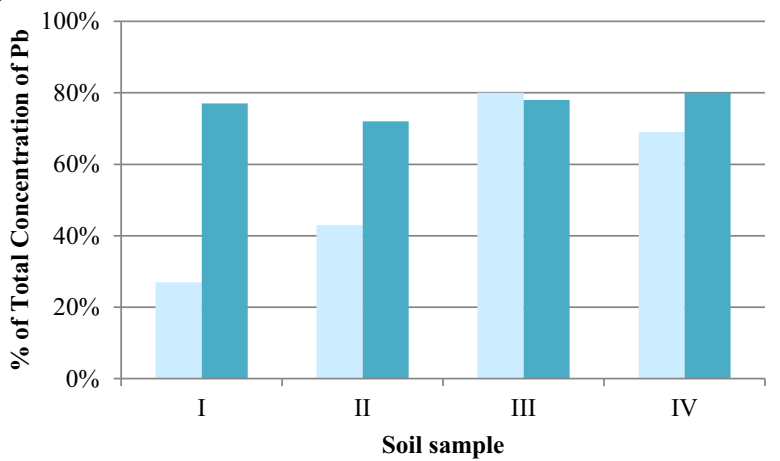

(c)

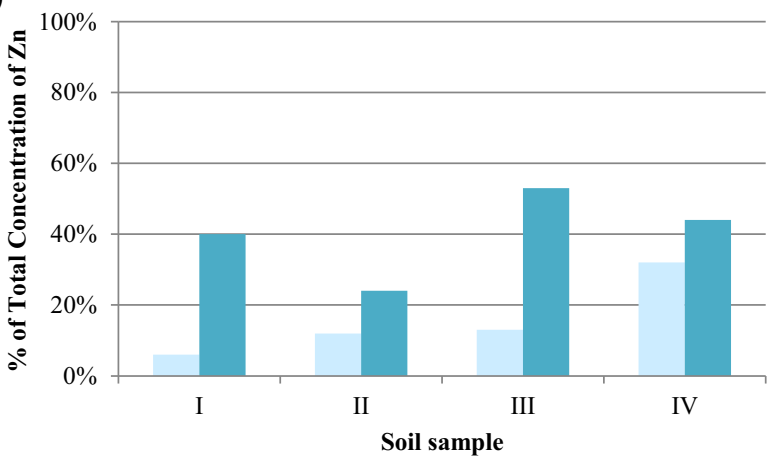

$1994 \square 2014$

Fig. 11 Bioavailable forms of metals (0.05 M EDTA) in topsoil samples as a $\%$ of total concentration of $\mathbf{a} \mathrm{Cd}, \mathbf{b} \mathrm{Pb}, \mathbf{c} \mathrm{Zn}$

environmental risk for topsoil, from very high to medium, was presented in the Olkusz area by three metals: $\mathrm{Cd}, \mathrm{Zn}$, and $\mathrm{Pb}$ (Table 5). The risk calculated for $\mathrm{Tl}$ was medium, and there was no environmental risk associated with the presence of As and Fe in topsoil.

\section{Discussion}

Soil investigations were carried out close to the flotation tailing dump of the Olkusz ore-bearing area on regular basis over the last two decades, i.e. starting in 1994 and then every 5 years until 2014. Analytical procedures and sample and soil processing methods considerably changed during that period. Metals contained in the soils samples collected in 1994 were extracted with a mixture of strong acids $\left(\mathrm{HCl}+\mathrm{HF}+\mathrm{HClO}_{4}\right)$. However, subsequent extractions of 1999, 2004, and 2009 involved a weaker reagent, a mixture of the nitric $(V)$ and hydrochloric acids. Various extraction methods could cause differences in sample decomposition and, thus, partitioning of metals between the samples collected in 1994 and those collected during the three subsequent campaigns.

The analyses of the data obtained from the national environment monitoring system and pertaining to the metal content in arable soils in the vicinity of the area indicated that the permissible metal contents specified in agricultural standards were exceeded only at one site of the national monitoring grid located on the eastern side of the Upper Silesian Region. However, referring to the same standards, our 20-year investigations established that the permissible values within the area were exceeded from several to several dozen times! That was a proof of existence of a long-term health hazard for the inhabitants, who, moreover, often grow edible fruits and vegetables in backyard gardens and garden plots.

The organic matter content, both in topsoil and vertical soil profiles, measured in 2009-2014, remained at similar levels. Besides, soil reaction did not change much on the area. However, the concentrations of anions in water solutions of topsoil significantly decreased: $\mathrm{Cl}^{-}$even 20 times, $\mathrm{SO}_{4}{ }^{2-}$ almost 1400 times, as well as those of $\mathrm{NO}_{3}{ }^{-}$.

The metal contents determined in 1994 were significantly higher than those of 2014, except for one sample (Sample I) in which the contents of $\mathrm{As}, \mathrm{Pb}$, and $\mathrm{Cd}$ increased. All metal contents, particularly those of $\mathrm{Cd}, \mathrm{Pb}$, and $\mathrm{Zn}$, identified in the samples collected in 1994 and 2014, significantly exceeded the permissible limits cited in RMŚ (2002). High amounts of As and Fe were also found (those two metals are not specified in the RMŚ 2002).

The total metal contents in topsoil samples significantly decreased in the soils west of the flotation tailing dump (Sites III and IV) and the total metal content decreased but not so distinctly in the soils east of that area. The total contents $\mathrm{As}, \mathrm{Cd}$, and $\mathrm{Pb}$ increased in the soil sampled at Site I.

Significant differences were identified in the topsoil fractions separated by the BCR sequential extraction, i.e. the fractions binding metals with various mobility. During the 20 years of studies, the proportions of metals bound in mobile forms increased in Sample I, and in the case of $\mathrm{Zn}$, the same occurred in Samples III and IV. The decrease of the mobile forms was demonstrated by $\mathrm{Cd}, \mathrm{Pb}$, and $\mathrm{Tl}$ in Sample II; $\mathrm{Pb}$ and $\mathrm{Zn}$ in Sample III, and $\mathrm{Cd}$ and $\mathrm{Pb}$ in Sample IV.

Tracing metal contents in vertical soil profiles in the past 20 years showed a general trend of metal contents 
(a)

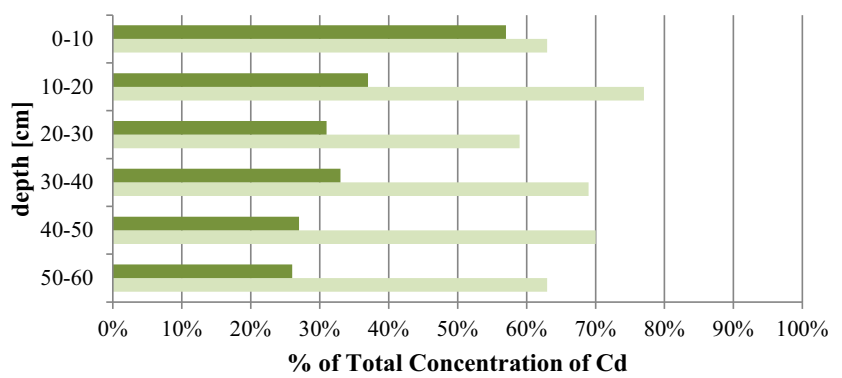

(c)

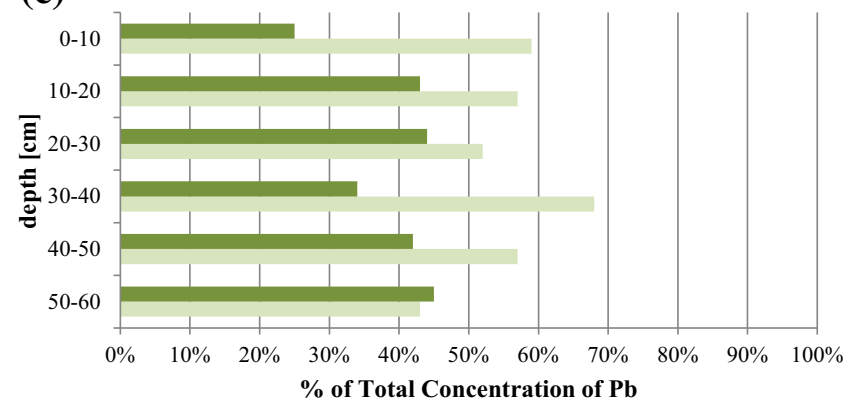

(b)

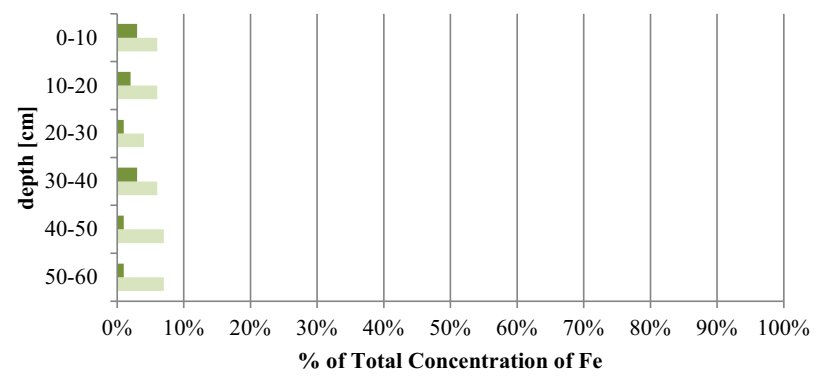

(d)

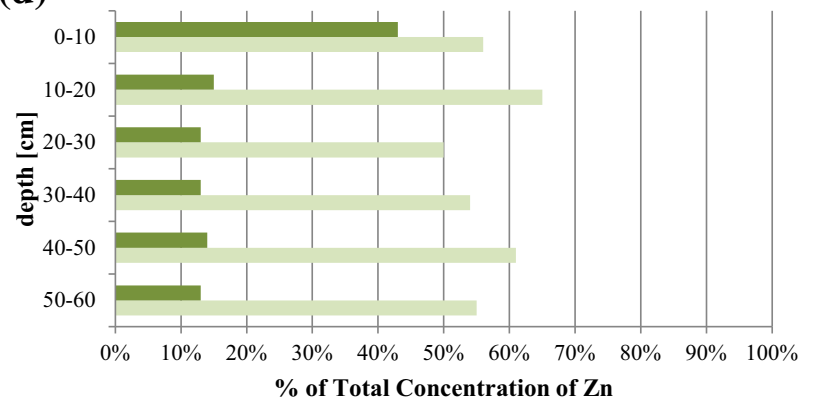

$\square$ I profile $\square$ II profile

Fig. 12 Bioavailable forms of metals (0.05 M EDTA) in soil profiles as a \% of total concentration of a $\mathrm{Cd}, \mathbf{b} \mathrm{Fe}, \mathbf{c ~} \mathrm{Pb}, \mathbf{d ~ Z n}$

Table 4 Five-degree scale of the RAC coefficient (Jain 2004; Singh et al. 2005)

\begin{tabular}{ll}
\hline Designation & $\begin{array}{l}\text { Metal concentration in carbonate } \\
\text { and exchangeable fractions }(\%)\end{array}$ \\
\hline No risk & $<1$ \\
Low risk & $1-10$ \\
Medium risk & $11-30$ \\
High risk & $31-50$ \\
Very high risk & $>50$ \\
\hline
\end{tabular}

consisting of $\mathrm{As}, \mathrm{Cd}, \mathrm{Fe}, \mathrm{Zn}$, and $\mathrm{Tl}$ decrease with depth. The $\mathrm{Pb}$ content in soils increased to the depth of about $30-40 \mathrm{~cm}$ and decreased below.

Metals concentrated in the topsoil containing several percents of organic matter: Sample I 6.6\% of organic matter and Sample II 3.6\%. That correlation also occurred at the depth $20-30 \mathrm{~cm}$ bgl in soil profiles, where the organic matter content increased again (2.8\% in Profile I). The downward migration of metals may have been stopped not only by organic matter, but also as a result of bioaccumulation by shallow root systems of plants, mainly grass varieties and other turf components, reaching $30 \mathrm{~cm}$.

The soil profiles also revealed differences in the fraction contents, separated by the BCR procedure and, consequently, the metal contents associated with those fractions.
Table 5 Risk assessment code (RAC) for topsoil samples of the Olkusz area

\begin{tabular}{|c|c|c|c|c|c|c|}
\hline \multirow{2}{*}{$\begin{array}{l}\text { Topsoil } \\
\text { sample }\end{array}$} & \multicolumn{6}{|l|}{ RAC } \\
\hline & As & $\mathrm{Cd}$ & $\mathrm{Fe}$ & $\mathrm{Pb}$ & $\mathrm{Tl}$ & $\mathrm{Zn}$ \\
\hline I & $\begin{array}{l}\text { No } \\
\text { risk }\end{array}$ & $\begin{array}{l}\text { Very } \\
\text { high } \\
\text { risk }\end{array}$ & $\begin{array}{l}\text { No } \\
\text { risk }\end{array}$ & $\begin{array}{c}\text { Very } \\
\text { high } \\
\text { risk }\end{array}$ & $\begin{array}{l}\text { Medium } \\
\text { risk }\end{array}$ & $\begin{array}{c}\text { Very } \\
\text { high } \\
\text { risk }\end{array}$ \\
\hline II & $\begin{array}{l}\text { No } \\
\text { risk }\end{array}$ & $\begin{array}{r}\text { High } \\
\text { risk }\end{array}$ & $\begin{array}{l}\text { No } \\
\text { risk }\end{array}$ & $\begin{array}{l}\text { High } \\
\text { risk }\end{array}$ & Low risk & $\begin{array}{l}\text { Medium } \\
\text { risk }\end{array}$ \\
\hline III & $\begin{array}{l}\text { Low } \\
\text { risk }\end{array}$ & $\begin{array}{c}\text { Very } \\
\text { high } \\
\text { risk }\end{array}$ & $\begin{array}{l}\text { No } \\
\text { risk }\end{array}$ & $\begin{array}{l}\text { Low } \\
\text { risk }\end{array}$ & $\begin{array}{l}\text { Medium } \\
\text { risk }\end{array}$ & $\begin{array}{c}\text { Very } \\
\text { high } \\
\text { risk }\end{array}$ \\
\hline IV & $\begin{array}{l}\text { No } \\
\text { risk }\end{array}$ & $\begin{array}{l}\text { Medium } \\
\text { risk }\end{array}$ & $\begin{array}{l}\text { No } \\
\text { risk }\end{array}$ & $\begin{array}{l}\text { Low } \\
\text { risk }\end{array}$ & No risk & $\begin{array}{l}\text { Medium } \\
\text { risk }\end{array}$ \\
\hline
\end{tabular}

The data accumulated over 20 years indicated a general trend of increasing $\mathrm{Cd}$ and $\mathrm{Zn}$ proportions, associated with mobile forms in Profile I and decreasing proportions in Profile II. The proportions of $\mathrm{Pb}$ decreased in both soil profiles.

Comparison of the results of years 1994 and 2014 showed that the proportions of bioavailable metals (i.e. those extracted with the $0.05 \mathrm{M}$ EDTA solution) increased as follows: Cd from 24-59 to 30-70\% of total metal content; Fe from 1-3 to 2-8\%; $\mathrm{Pb}$ from $27-80$ to $72-80 \%$; and $\mathrm{Zn}$ from $6-32$ to $24-53 \%$. 
A potential risk of releasing substantial volumes of those metals into the environment was identified owing not only to significant total contents of $\mathrm{Cd}, \mathrm{Pb}$, and $\mathrm{Zn}$ in soils, but also their contents in the exchangeable forms (BCR procedure Step I) and high metal proportions in bioavailable forms (EDTA extraction). The process could be followed by penetration of metals into plants and higher links of the trophic chain.

The contents of the studied metals significantly decreased in the last 20 years. Undoubtedly, that was a result of the closure of environment-threatening industrial plants in the Upper Silesia, modernization of manufacturing technologies, fitting of environmentally friendly installations, introduction of more restrictive environment protection laws and regulations, as well as more effective methods of law implementation and inspections. Unfortunately, the decrease of metal contents in topsoil was insufficient over the last 20 years. The metal amounts were definitely too high and that has not changed much. Such a situation may result from continuous dusting of the flotation tailings dumps, which contain considerable amounts of metals, and the emission of industrial dusts containing heavy metals into the atmosphere, despite emission control measures implemented in plants, followed by deposition of atmospheric dusts transported at short or long distance (the latter arrive mainly from the Upper Silesia).

The environmental indicators ( $\mathrm{S}, \mathrm{CF}$, and PLI) and the potential environmental risk (RAC) calculated by the authors showed that, despite decreasing amounts of metals in the area soils in the last 20 years, a significant and progressing contamination of soils developed on the area owing to the presence of $\mathrm{Cd}, \mathrm{Zn}$, and $\mathrm{Pb}$ and at least a high environmental risk resulted from the contents and forms of those elements' presence in topsoil.

Considering the fact that the improvement of the environment quality is a long process requiring reduction of pollutant emissions from many sources, everybody should be aware of the future of soil pollution in the Olkusz area today. The surface soil layers will remain to be polluted for long with metals, including potential harmful elements, above the permissible levels. Reduction of emissions will not bring immediate improvement of the quality of all the environment components, particularly of earth surface where the accumulated pollutants will persist for many years.

\section{Conclusions}

The results of investigations carried out on the Olkusz orebearing area soils over 20 years showed the following:
1. A tendency of decreasing metal content in topsoil. Metals were concentrated in the soils situated east of the flotation tailing dump, a shorter distance from pollution sources. Such distribution resulted from the domination of western winds in Poland (long-distance transport) and fall of pollutants close to emitters (shortdistance transport).

2. The metal contents significantly decreased with depth in the soil profiles of 2014. Specific metal amounts were lower than those established in 1994. The metal amounts were lower in topsoil than those recorded in 1994, but not so distinctly in comparison to the metal contents of deeper profile sections.

3. Both in topsoil and soil profiles, the exchangeable forms (BCR procedure Step I) contained most of $\mathrm{Cd}$ (in the proportion of up to $83 \%$ of total metal content), $\mathrm{Zn}$ (up to $72 \%$ ), and $\mathrm{Pb}$ (up to 60\%), whereas As, Fe and $\mathrm{Tl}$ were either associated with the hardly movable forms upon extraction or remained in the extraction residuum.

4. Those proportions of the forms that carried mobile and bioavailable metals (high total metal values) pointed at: (1) a considerable hazard induced by $\mathrm{Cd}, \mathrm{Pb}$, and $\mathrm{Zn}$ in plants and (2) a possibility of transferring high doses of those metals into higher links of the trophic chain.

5. The RAC coefficients calculated for the specified metals indicated that the highest environmental risk, ranging from very high to medium, was caused by $\mathrm{Cd}$, $\mathrm{Zn}$, and $\mathrm{Pb}$ contained in the Olkusz area soils and partly by $\mathrm{Tl}$. However, there was no environmental risk associated with the presence of As and Fe in topsoil.

Acknowledgements The research was supported within the framework of Statutory Research Grant No. 11.11.140.199 by the AGH University of Science and Technology.

Open Access This article is distributed under the terms of the Creative Commons Attribution 4.0 International License (http://crea tivecommons.org/licenses/by/4.0/), which permits unrestricted use, distribution, and reproduction in any medium, provided you give appropriate credit to the original author(s) and the source, provide a link to the Creative Commons license, and indicate if changes were made.

\section{References}

Baran A, Czech T, Wieczorek J (2014) Chemical properties and toxicity of soils contaminated by mining activity. Ecotoxicology 23(7):1234-1244

Bednarek R, Dziadowiec H, Pokojska U, Prusinkiewicz Z (2004) Badania ekologiczno-gleboznawcze. PWN, Warszawa

Bilans Zasobów Złóż Kopalnianych w Polsce (2013) Stan 31.12. 2012 r. Państwowa Służba Geologiczna, Państwowy Instytut Geologiczny, Warszawa, p 54 
BN-75/9180-03 (1975) Analiza chemiczno-rolnicza gleby. Oznaczanie wartości $\mathrm{pH}$. PKN

BN-78/9180-11 (1978) Gleby i utwory mineralne. Podział na frakcje i grupy granulometryczne. PKN

Cabała, J (2001) Development of oxidation in $\mathrm{Zn}-\mathrm{Pb}$ deposits in Olkusz area. In: Piestrzyński A (ed.) Mineral Deposits at the Beginning of the 21st century. Balkema, pp. 21-124

Cabała J (2009) Metale ciężkie w środowisku glebowym olkuskiego rejonu eksploatacji rud $\mathrm{Zn}-\mathrm{Pb}$. Wyd, Katowice, p 128

Cabała J (2010) Cynk w technosferze. Górnictwo Geol 5(4):63-76

Cabrera F, Clemente L, Díaz-Barrientos E, López R, Murillo JM (1999) Heavy metal pollution of soils affected by the Guadiamar toxic flood. Sci Total Environ 242:117-129

Chodak M, Gołębiewski M, Morawska-Płoskonka J, Kuduk K, Niklińska M (2013) Diversity of microorganisms from forest soils differently polluted with heavy metals. Appl Soil Ecol 64:7-14

Chrastný V, Vaněk A, Teper L, Cabała J, Procházka J, Pechar L, Drahota P, Penížek V, Komárek M, Novák M (2012) Geochemical position of $\mathrm{Pb}, \mathrm{Zn}$ and $\mathrm{Cd}$ in soils near the Olkusz mine/ smelter, South Poland: effects of land use, type of contamination and distance from pollution source. Environ Monit Assess 184:2517-2536

Council of the European Communities (1986) Directive (86/278/ EEC) on the protection of the environment, and in particular of the soil, when sewage sludge is used in agriculture. Off $\mathrm{J}$ Eur Commun L181:6-12

Danek M (2007) The influence of industry on Scots Pine stands in the South-eastern part of the Silesia-Cracow Upland (Poland) on the basis of dendrochronological analysis. Water Air Soil Pollut 185:265-277

Dmuchowski W, Gworek B, Gozdowski D, Baczewska A, Muszyńska A (2011) Zanieczyszczenie powietrza metalami ciężkimi w rejonie huty cynku i ołowiu w Bukownie koło Olkusza. Przemysł Chem 90(2):223-228

Dworak TZ, Czubak J (1990) Stan zanieczyszczenia środowiska rejonu olkuskiego w świetle interpretacji obrazów satelitarnych. Zeszyty Naukowe Akademii Górniczo-Hutniczej im. S. Staszica, Sozologia i Sozotechnika 1368(32):21-31

Girczys J, Sobik-Szołtysek J (2002) Odpady przemysłu cynkowoołowiowego. Seria Monografie nr 87, Wydawnictwo Politechniki Częstochowskiej, Częstochowa

Gorlach E, Gambuś F (1995) Zawartość metali ciężkich w glebach i roślinach łąkowych północno-zachodnich rejonach województwa krakowskiego sąsiadującymi z terenami eksploatacji górniczej i przeróbki rud ołowiu i cynku. Acta Agraria et Silvestria ser. Agraria 33:61-72

Gruszczyński S, Trafas M, Żuławski C (1990) Charakterystyka gleb w rejonie Olkusza. Zeszyty Naukowe Akademii GórniczoHutniczej im. S. Staszica, Sozologia i Sozotechnika 32(1368):113-122

Gruszecka A (2011) Badane metale ciężkie w wodach i osadach rzecznych oraz glebach w otoczeniu składowisk odpadów górniczych i hutniczych w Bukownie (Polska) i Mansfeld (Niemcy). Rozprawy doktorskie. Monografie. Wydawnictwa AGH, Kraków

Gruszecka A, Wdowin M (2013) Characteristics and distribution of analyzed metals in soil profiles in the vicinity of a postflotation waste site in the Bukowno region, Poland. Environ Monit Assess 185:8157-8168

Huot H, Faure P, Biache C, Lorgeoux C, Simonnot MO, Morel JL (2014) A Technosol as archives of organic matter related to past industrial activities. Sci Total Environ 487:389-398

Jain CK (2004) Metal fractionation study on bed sediments of River Yamuna, India. Water Res 38:569-578
Janusz W, Popiołek E (1993) Środowisko w olkuskim okręgu eksploatacji rud cynku i ołowiu. Rudy Metale 38(1):6-9

Kabata-Pendias A (1989) Zanieczyszczenia pierwiastkami śladowymi użytków rolnych. In: Wybrane zagadnienia związane $\mathrm{z}$ chemicznym zanieczyszczeniem gleb. Komitet Naukowy przy Prezydium PAN Człowiek i Środowisko, Wrocław

Kabata-Pendias A, Pendias H (1999) Biogeochemia pierwiastków śladowych. Wydawnictwo Naukowe PWN, Warszawa

Kabata-Pendias A, Pendias H (2000) Trace elements is soils and plants. CRC Press, Boca Raton

Kabata-Pendias A, Motowicka-Terelak T, Terelak H, Witek T (1993) Ocena stopnia zanieczyszczenia gleb i roślin metalami ciężkimi i siarką-ramowe wytyczne dla rolnictwa. Wydawnictwo Instytutu Upraw Nawożenia i Gleboznawstwa, Puławy 53:1-20

Kabata-Pendias A, Piotrowska M, Motowicka-Terelak T, Maliszewska-Kordybach B, Filipiak K, Krakowiak A, Pietruch C (1995) Podstawy oceny chemicznego zanieczyszczenia gleb. Metale ciężkie, siarka, WWA. Biblioteka Monitoringu Środowiska, Warszawa

Kapeja E, Janusz W, Zając KP, Zurek R (1990) Stan zanieczyszczenia powietrza atmosferycznego w rejonie Kombinatu Górniczo-Hutniczego "Bolesław", Zeszyty Naukowe Akademii Górniczo-Hutniczej im. S. Staszica, Sozologia i Sozotechnika 1368(32):11-20

Kapusta P, Sobczyk $Ł$ (2015) Effects of heavy metal pollution from mining and smelting on enchytraeid communities under different land management and soil conditions. Sci Total Environ 536:517-526

Kicińska A (2009) Arsen i tal w glebach i roślinach rejonu Bukowna. Ochr Środ i Zasob Natur 40:199-208

Kicińska A (2011) Formy występowania oraz mobilność cynku, ołowiu i kadmu w glebach zanieczyszczonych przez przemysł wydobywczo-metalurgiczny. Ochr Środ i Zasob Natur 49:152-162

Kicińska A, Wójcik R (2011) The influence of $\mathrm{Zn-Pb}$ flotation waste and slag on plants-soils system. Acta Environmentalica Universitatis Comenianae, Bratislava: Univerzita Komenského 19(1):164-168

Kicińska-Świderska A (1999) Metale ciężkie w glebach i w roślinach na wybranych obszarach oddziaływania przemysłu hutniczego. Praca doktorska, AGH, Kraków

Kicińska-Świderska A (2004) Wpływ składu mineralnego i geochemicznego na uwalnianie metali $\mathrm{z}$ pyłów przemysłowych $\mathrm{z}$ ZGH „Bolesław” w Bukownie. Geologia: kwartalnik Akademii Górniczo-Hutniczej im. St. Staszica w Krakowie 30(2):191-205

Kicki J (1997) Technologia eksploatacji złóż rud cynku i ołowiu. In: Ney R (ed) Monografia Surowce mineralne Polski, Surowce metaliczne cynk ołów. Wydawnictwo CPPGSMiE PAN, Kraków

Krzaklewski W, Barszcz J, Małek S, Kozioł K, Pietrzykowski M (2004) Contamination of forest soils in the vicinity of the sedimentation pond after zinc and lead ore flotation (in the region of Olkusz, southern Poland). Water Air Soil Poll 159:151-164

Li X, Thornton I (2001) Chemical partitioning of trace and major elements in soils contaminated by mining and smelting activities. Appl Geochem 16:1693-1706

Liu W, Zhao J, Ouyang Z, Söderlund L, Liu G (2005) Impacts of sewage irrigation on heavy metal distribution and contamination in Beijing, China. Environ Int 31:805-812

Majcherek A (1991) Górnictwo i przeróbka mechaniczna a ochrona środowiska. Rudy Met 36(4):124-126

Miśkowiec P, Łaptaś A, Zięba K (2015) Soil pollution with heavy metals in industrial and agricultural areas: a case study of Olkusz District. J Elem 20(2):353-362

Monitoring gleb ornych w Polsce w latach 1995-2010. http://www. gios.gov.pl/chemizm gleb/index.php?mod=monit 
Nannoni F, Protano G, Riccobono F (2011) Fractionation and geochemical mobility of heavy metals in soils of a mining area in northern Kosovo. Geoderma 161:63-73

Nowicki M (1993) Strategia ekorozwoju Polski. Agencja Reklamowo-Wydawnicza A. Grzegorczyk, Warszawa

Oades JM (1988) The retention of organic matter in soils. Biogeochemistry 5:35-70

Pająk M, Szostak M, Socha J, Wężyk P, Tompalski P, Mucha S, Lesiak M (2012) Zastosowanie narzędzi informatycznych dla oceny poziomu zanieczyszczenia gleb metalami ciężkimi w rejonie ZGH "Bolesław" w Bukownie. Archiwum Fotogrametrii Kartografii i Teledetekcji 23:315-326

Pająk M, Gąsiorek M, Cygan A, Wanic T (2015) Concentrations of $\mathrm{Cd}, \mathrm{Pb}$ and $\mathrm{Zn}$ in the top layer of soil and needles of Scots Pine (Pinus sylvestris L.); a case study of two extremely different conditions of the forest environment in Poland. Fresen Environ Bull 24(1):71-76

Pająk M, Błońska E, Frąc M, Oszust K (2016) Functional diversity and microbial activity of forest soils that are heavily contaminated by lead and zinc. Water Air Soil Pollut 227:348

Paulo A, Wnuk R (2012) Złoże rud cynku i ołowiu Pomorzany po 36 latach eksploatacji-zmienna wizja wystarczalności zasobów. Rudy Met 57(2):67-75

PN-ISO 10390 (1997) Jakość gleby. Oznaczanie pH

PN-ISO 11466 (2002) Jakość gleby. Ekstrakcja pierwiastków śladowych rozpuszczalnych w wodzie królewskiej

Quevauviller Ph, Rauret G, Lopez-Sanchez JF, Rubio R, Ure A, Muntau H (1997) Certification of trace metal extractable contents in a sediment reference material (CRM 601) following a threestep sequential extraction procedure. Sci Total Environ 205:223-234

RMŚ (2002) Regulation of the Minister of the Environment on the standards of soil quality and the standards of ground quality (Off. Gazette 2002, No. 165, item 1359)

Rodríguez L, Ruiz E, Alonso-Azcárate J, Rincón J (2009) Heavy metal distribution and chemical speciation in tailings and soils around a Pb-Zn mine in Spain. J Environ Manag 90:1106-1116

Sass-Gustkiewicz M (1995) Upper Silesian Zn-Pb ore deposits in the light of solution transfer. Zeszyty Naukowe Akademii Górniczo Hutniczej Geologia 31:119
Sass-Gustkiewicz M (1996) Internal sediments as a key to understanding the hydrothermal karst origin of the Upper Silesian Zn$\mathrm{Pb}$ ore deposits. Soc Econ Geol Spec Publ 4:171-181

Sass-Gustkiewicz M (1997) Revised and completed paragenetic order of minerals in the Pomorzany lead-zinc deposit, Upper Silesian region, Poland. Mineral Pol 28:46-80

Sass-Gustkiewicz M, Mayer W, Góralski M, Leach DL (2001) Zawartość metali ciężkich w glebach na obszarach eksploatacji rud $\mathrm{Zn}-\mathrm{Pb}$ w rejonach olkuskim i chrzanowskim. PAN, IGSMiE, Sympozja i Konferencje 49:189-208

Singh KP, Mohan D, Singh VK, Malik A (2005) Studies on distribution and fractionation of heavy metals in Gomti river sediments - a tributary of the Ganges, India. J Hydrol 312:14-27

Sroczyński W (1997) Wpływ eksploatacji, przeróbki i przetwórstwa rud cynku i ołowiu na środowisko przyrodnicze. In: Ney R (ed) Monografia Surowce mineralne Polski, Surowce metaliczne cynk ołów, Wydawnictwo CPPGSMiE PAN, Kraków

Stefanowicz AM, Woch MW, Kapusta P (2014) Inconspicuous waste heaps left by historical $\mathrm{Zn}-\mathrm{Pb}$ mining are hot spots of soil contamination. Geoderma 235-236:1-8

Szarek-Łukaszewska G, Grodzińska K (2011) Grasslands of a Zn-Pb post-mining area (Olkusz ore-bearing region, S Poland). Pol Bot J 56(2):245-260

Tembo BD, Sichilongo K, Cernak J (2006) Distribution of copper, lead, cadmium, and zinc concentrations in soils around Kabwe town in Zambia. Chemosphere 63:497-501

Trafas M, Gruszczyński S, Gruszczyńska J, Zawodny Z (1990) Zmiany własności gleb wywołane wpływami przemysłu w rejonie olkuskim. Zeszyty Naukowe Akademii Górniczo-Hutniczej im. S. Staszica, Sozologia i Sozotechnika 1368(32):143-162

Trafas M, Eckes T, Gołda T (2006) Lokalna zmienność zawartości metali ciężkich w glebach okolicy Olkusza. Inżynieria Środowiska 11(2):127-144

Turski R (1971) Substancja organiczna gleb terenów erodowanych. Roczniki Gleboznawcze 22(1):19-57

Verner JF, Ramsey MH, Helios-Rybicka E, Jędrzejczyk B (1996) Heavy metal contamination of soils around $\mathrm{Pb}-\mathrm{Zn}$ smelter in Bukowno, Poland. Appl Geochem 11:11-16

WHO (1988) Urbanisation and its implications for child health: potential for action. WHO, Geneva 